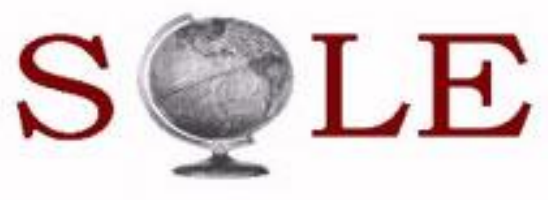

The Society of Labor Economists

NORC at the University of Chicago

Interindustry Variation in the Costs of Job Displacement

Author(s): William J. Carrington and Asad Zaman

Source: Journal of Labor Economics, Vol. 12, No. 2 (Apr., 1994), pp. 243-275

Published by: The University of Chicago Press on behalf of the Society of Labor

Economists and the NORC at the University of Chicago

Stable URL: https://www.jstor.org/stable/2535276

Accessed: 13-02-2019 06:04 UTC

JSTOR is a not-for-profit service that helps scholars, researchers, and students discover, use, and build upon a wide range of content in a trusted digital archive. We use information technology and tools to increase productivity and facilitate new forms of scholarship. For more information about JSTOR, please contact support@jstor.org.

Your use of the JSTOR archive indicates your acceptance of the Terms \& Conditions of Use, available at https://about.jstor.org/terms

NORC at the University of Chicago, Society of Labor Economists, The University of Chicago Press are collaborating with JSTOR to digitize, preserve and extend access to Journal of Labor Economics 


\title{
Interindustry Variation in the Costs of Job Displacement
}

\author{
William J. Carrington, Johns Hopkins University
}

Asad Zaman, Bilkent University

Job displacement entails a substantial wage reduction for most displaced workers. We show that the mean reduction, the tenure profile of reductions, and the experience profile of reductions all vary substantially across industries. We then link this interindustry variation to analogous variation in firm size, unionization, wage levels, and the incidence of employer-provided training. While these industry characteristics explain some of the interindustry variation in mean wage reductions, they do not explain variation in the tenure or experience profiles of wage reductions.

\section{Introduction}

Renewed political concern for workers displaced in plant closings and mass layoffs has led to several new and expensive federal programs. For example, the 1988 Economic Dislocation and Worker Adjustment Assistance Act allocates 1 billion dollars annually for retraining displaced workers. As another example, since 1991 Congress has repeatedly extended the maximum duration of unemployment benefits beyond 26 weeks, at a cost

We thank Chongshan Liu for research assistance and Bruce Hamilton, Kristin McCue, Chris Ruhm, Ken Troske, and seminar participants at Johns Hopkins and Texas A\&M for helpful comments on previous versions of this article. In addition, William Carrington thanks the members of his dissertation committee: Gary Becker, Sherwin Rosen, and especially Robert Topel.

[Journal of Labor Economics, 1994, vol. 12, no. 2]

(C) 1994 by The University of Chicago. All rights reserved.

0734-306X/94/1202-0001\$01.50 
of nearly 10 billion dollars. ${ }^{1}$ This enormous expense may be justified on equity grounds since recent research has shown that job displacement is costly for most workers, in terms of both increased unemployment (Addison and Portugal 1987) and reduced earnings on reemployment (Podgursky and Swaim 1987; Ruhm 1991; Jacobson, LaLonde, and Sullivan 1993). However, with so much money being directed toward displaced workers, it is imperative that we identify those particular workers most in need of assistance.

Previous research has identified several factors correlated with the difficulty of postdisplacement adjustments (Addison and Portugal 1987; Podgursky and Swaim 1987; Kletzer 1989; Topel 1990; Ruhm 1991). While studies differ in the exact weight attributed to each factor, most have emphasized a worker's employment history, particularly the level of firmspecific and general labor market experience, and the general condition of the locale and industry from which the worker was displaced (Howland and Peterson 1988; Carrington 1993). The purpose of this article is to examine the extent to which the costs of displacement and the importance of these factors vary across industries. Some authors (e.g., Kletzer 1991) have documented blue-collar/white-collar differences in displacement-induced wage reductions. However, there has been little attention to more detailed interindustry variation in wage reductions, and there has been almost no attention to interindustry variation in the determinants of displacement-induced wage reductions.

This is unfortunate because industries are apt to differ both in the size of displacement-induced wage reductions and in the determinants of those reductions. To take two extreme examples, consider the construction industry and the durable manufacturing industry. In construction, firm affiliation is often less important than membership in trade unions and guilds (Mills 1989). In this context, it would be surprising if firm displacement mattered independently of more general industry conditions. In contrast, employment relationships are often quite important in durable manufacturing, where wages are often set according to strict seniority rules. For this industry, firm-level conditions are probably quite important, even conditioned on more general labor market conditions. This reasoning suggests that targeting certain industries may improve the efficacy of displaced worker assistance programs.

${ }^{1}$ These new programs are merely extensions of the federal effort to assist displaced workers. The 1988 Worker Adjustment and Retraining Notification Act requires that large employers provide employees with 60 days advance notice of layoffs. Other programs predate recent political concern. For example, the 25-year-old Trade Adjustment Assistance Program, designed to assist workers displaced by foreign trade, had a 1992 budget of 216 million dollars. 
We pursue these issues with data drawn from the 1984, 1986, and 1988 Displaced Worker Surveys that were appended to the January Current Population Surveys of those years. We focus on interindustry differences in the mean of displacement-induced wage reductions and on differences in the role of employment history in determining those reductions. More specifically, using standard industrial classification, we explore differences across 10 "one-digit" industries and, separately, across 50 "two-digit" industries. With respect to interindustry variation in mean wage reductions, our main finding is that, while most industries are clustered around a $10 \%$ wage reduction, there are a few important outliers. For example, mean wage reductions are particularly large in the mining industries and particularly small in the service industries. As for the role of work history in determining wage reductions, we find that in most industries workers with 10 years of predisplacement job tenure lose about $13 \%$ more in weekly wages than do similar workers with little or no predisplacement job tenure. However, there are again some notable exceptions. For example, the relationship between tenure and wage reductions is particularly weak in construction and particularly strong in primary metal manufacturing.

After documenting interindustry variation in the costs of displacement, we ask whether the variation can be explained by interindustry differences in unionization, average wage levels, average firm size, and the incidence of employer-provided training. This exercise is interesting from two perspectives. First, the Displaced Worker Surveys lack data on many of the factors (e.g., unionization) that might affect the costs of job displacement. As a result, an interindustry analysis is a useful substitute for individuallevel variation in unionization, and so forth. Second, the analysis can be viewed as a complement to the literature on interindustry variation in wage levels (e.g., Krueger and Summers 1988). Our main finding is that displacement-induced wage reductions tend to be largest in those industries that are highly unionized, pay high wages, have large firms, and frequently provide informal on-the-job training. However, we are unable to explain much of the interindustry variation in the tenure and experience profiles of wage reductions.

This article proceeds as follows. Section II describes the data drawn from the Displaced Worker Surveys and several auxiliary data sets. One of the challenges of this exercise is that we have small samples for many of these industries, particularly at the two-digit level. The small samples mean that industry-by-industry analyses are quite imprecise for the smaller industries. These small sample considerations lead us to the use of Empirical Bayes techniques that we describe and motivate in Section III. Section IV presents our analysis of interindustry variation in the size and determinants of the displacement-induced costs. Section V relates interindustry variation in these dimensions to a few underlying differences in the structure of each industry. Section VI concludes. 


\section{Data}

The basic data for this study come from the Displaced Worker Surveys (DWS) that were administered in January of 1984, 1986, and 1988. ${ }^{2}$ The DWS surveys are supplements to the Current Population Survey (CPS) that are administered if the respondent answered "yes" to the following question: "In the past five years, have you lost or left a job because of a plant closing, an employer going out of business, a layoff from which you were not recalled, or other similar reasons?" For those answering positively, the survey records information on the predisplacement job and the worker's experience since displacement.

We restricted the sample to male workers between the ages of 21 and 63 who were displaced in plant closings or mass layoffs from full-time, private-sector jobs. We excluded workers who were displaced from selfemployment or for unspecified reasons, largely because the notion of displacement seems ill defined in such cases. These selection criteria leave us with a sample of 11,065 displaced workers. We were interested in distinguishing the effects of firm-level displacement from the adverse effects of working in a state or industry that is generally in decline. ${ }^{3}$ Therefore, we matched the DWS data to information drawn from County Business Patterns (CBP) data that record employment levels by state, and within states, by two-digit industry. ${ }^{4}$ Matching state-level CBP information to the DWS is complicated by the fact that the DWS records only current state of residence and whether or not the respondent has moved geographically since the displacement. As a result, we have no direct information on the predisplacement state for movers. One approach to this problem is to throw out everyone who moved. ${ }^{5}$ However, since many of the moves could

${ }^{2}$ The DWS was also administered in 1990 and 1992. We do not use these latter data sets because 1990 local state and industry data were not available as of this writing.

${ }^{3}$ Carrington (1993) considers the effect of the local occupational market on postdisplacement outcomes, in addition to the local industry and state-level factors considered here. It appears that occupational factors add little to the analysis, although this could be due to the fact that data limitations force occupations to be considered at a one-digit level.

${ }^{4}$ The Census Bureau maintains the County Business Patterns series that tracks employment, payroll, and number of establishments by geographical location and detailed industry. The CBP is compiled from a variety of sources, including the Annual Survey of Manufactures, the Annual Company Organization Survey, and Internal Revenue Service payroll files. These data included Federal Insurance Contributions Act (FICA)-covered employment through 1977, and almost all employment at FICA firms thereafter. Self-employed workers and employees at nonFICA firms are not included, so the CBP undercounts employment in small firms.

${ }^{5}$ This is the approach followed in Carrington (1993). 
have been intrastate, this throws out many valid observations. ${ }^{6}$ An alternative approach is to simply treat all moves as if they were intrastate. We chose the latter approach because we wanted to maximize the sample size in the smaller industries. We have done limited experimentation with these alternative methods, and the general flavor of the results does not appear to be sensitive to the treatment of movers. ${ }^{7}$

We summarized the CBP information on local conditions in a simple fashion. For state-level data, we calculated the trend in state employment for a given year as the average log of state employment changes over the previous 3 years. We call this variable STATETREND. After limited experimentation, we concluded that most state-level employment series are close to a random walk with $\mathrm{drift}^{8}{ }^{8}$ Therefore we computed the innovation to state employment, which we call STATESHOCK, as

\section{$\operatorname{STATESHOCK}(t)$}

$$
=[\operatorname{EMP}(t)-\operatorname{EMP}(t-1)]-\operatorname{STATETREND}(t-1),
$$

where $\operatorname{EMP}(t)$ is the log of state employment. These variables are computed as of the year of displacement, not the year of the survey. We computed analogous variables for the displaced workers' state-level two-digit industry. These variables are called INDTREND and INDSHOCK. Definitions of other variables used in the analysis are contained in the Appendix. The variable definitions are straightforward with the exception of WAGECHANGE, which will be discussed shortly.

Table 1 presents selected features of the data for the whole sample, broken apart by survey year. The first five rows show that these workers were typically displaced in states and local industries that were generally in distress. The mean shock to state employment (STATESHOCK) in the year of displacement was $-0.5 \%$, while the mean shock to the state's twodigit industry (INDSHOCK) was almost $-2 \%$. A comparison across survey years shows that these conditions were worse for the 1984 survey, mostly because it bracketed the 1981-82 recession. Rows 6-9 display some of the demographic characteristics of displaced workers. A comparison of these figures with populationwide averages shows that displaced workers are

\footnotetext{
${ }^{6}$ The Census Bureau estimates that roughly $40 \%$ of the entire U.S. population changed homes between 1980 and 1985 , but that only $8.5 \%$ moved across state lines during this period (U.S. Department of Commerce, 1987a, table no. 29).

${ }^{7}$ Movers tend to be younger and more educated than nonmovers, which is consistent with populationwide mobility patterns. Movers also tend to have larger wage reductions than nonmovers.

${ }^{8}$ We based this conclusion on our finding that there was very little autocorrelation in differences of trend residuals for most state employment series.
} 
Table 1

Selected Means, by Survey Year

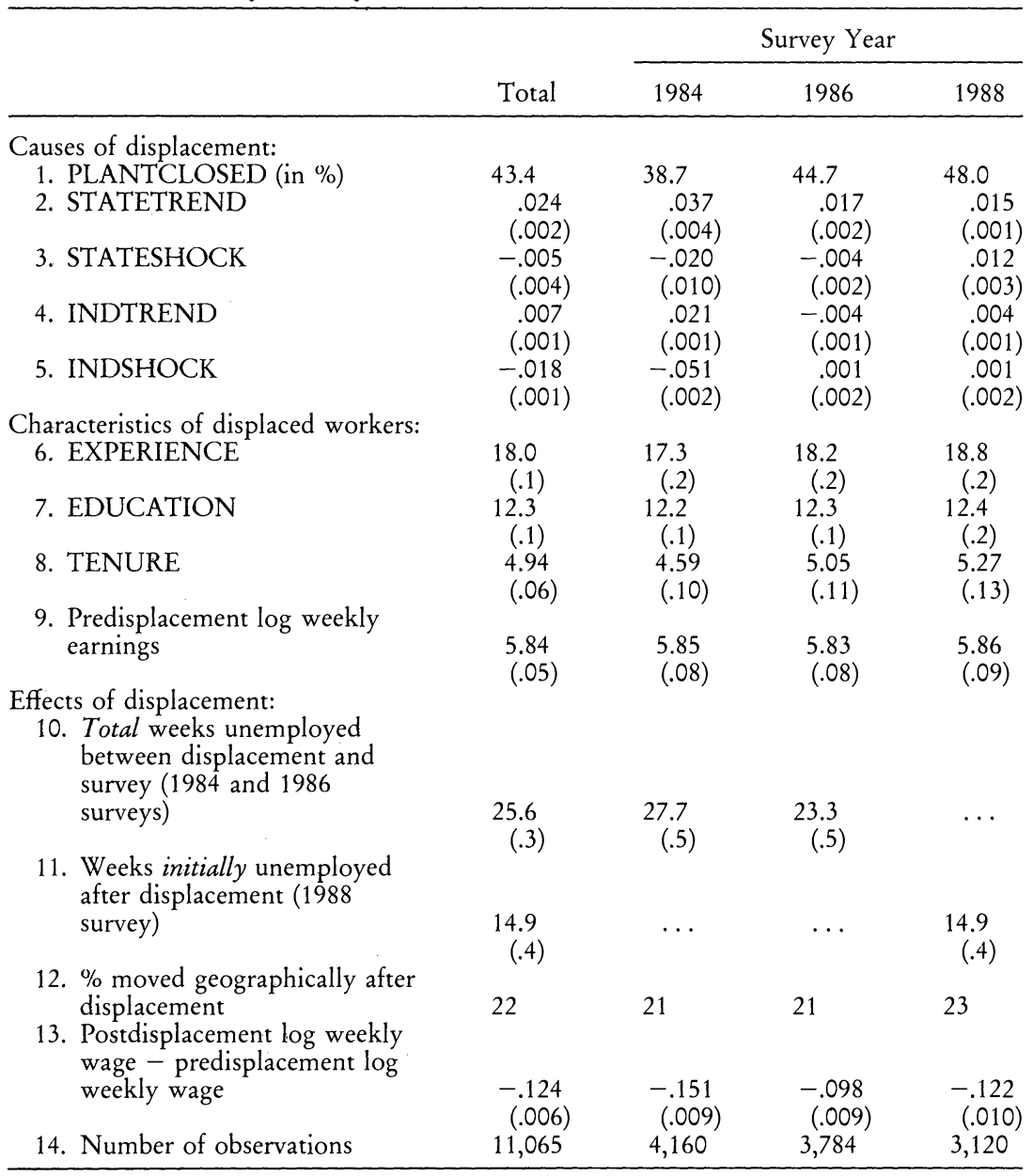

NOTES.-Data are drawn from 1984, 1986, 1988 Displaced Worker Surveys and the County Business Patterns data described in the text. Standard errors are in parentheses.

younger, less educated, and have lower job tenure and lower wages than the rest of the male population. ${ }^{9}$

${ }^{9}$ Recent research (e.g., Juhn, Murphy, and Pierce 1993) has shown that men with these demographic characteristics have generally seen their earnings erode during the 1980s, independently of job displacements. Therefore, these wage reductions may overstate the effect of job displacement per se. However, Farber (1993) compares the earnings changes of displaced workers with the earnings changes of similar workers in the entire CPS and finds that displacement does 
Rows 10-13 of table 1 report some of the effects of job displacement. In 1984 and 1986, the DWS recorded the total number of weeks that displaced workers had been unemployed in the period between the displacement and the survey date. This figure includes time initially spent in unemployment after the displacement, as well as time spent in any subsequent unemployment spells. In 1988, the DWS refined the question so that it recorded only the number of weeks unemployed in the initial postdisplacement unemployment spell. By either measure, displaced workers spent significant time in unemployment after being displaced. Row 13 shows that the mean change in log weekly wages between the displacement date and the survey date was approximately $-12 \%$, although this varied somewhat across survey years. ${ }^{10}$

A complete assessment of the costs of job displacement would incorporate unemployment (perhaps adjusted for unemployment insurance recipiency), as well as reductions in both wages and benefits. However, such a study is beyond the scope of this article, and from here on we focus exclusively on interindustry variation in the reduction in log weekly wages associated with displacement. ${ }^{11}$ Our main investigative technique will be industry-specific regressions of the change in log weekly wages on measures of work history (TENURE, TENURE2, EXPERIENCE, EXPERIENCE2, EDUCATION) and local demand conditions (PLANTCLOSED,

adversely affect a worker's position in the earnings distribution of apparently similar men. Another concern that arises here is that wage losses and unemployment may be temporary phenomena that are quickly erased. This issue is difficult to address in the DWS because we only have one postdisplacement measurement for each individual. Ruhm (1991) has examined the postdisplacement pattern of earnings for displaced workers in the Panel Study for Income Dynamics. He finds that while some of the earnings loss is ephemeral, a substantial component appears to persist for quite some time.

${ }^{10}$ We deflated all weekly wage figures to $1982-84$ dollars using the consumer price index.

${ }^{11}$ Even this simple task is complicated by the fact that we do not have measurements of wage reductions for the $45 \%$ of displaced workers who are not employed at the survey date. Some authors have attempted to model the reemployment decision in an effort to correct for the sample selection bias. In our view, these efforts have achieved quite limited improvements over standard ordinary least squares (OLS) procedures applied to the reemployed sample. For this reason, and because our Empirical Bayes methods are not amenable to sample selection techniques, we do not model the sample selection issue. We should note, however, that the fraction of displaced workers with a current job ranges from $70 \%$ in some industries to $50 \%$ in some others and, as a result, sample selection bias may affect some industries more than others. The interindustry correlation between the fraction of workers with a current job and the average wage reduction (based on those that do have a current job) is .26 with a $p$-value of .06 . While this suggests that interindustry variation in wage reductions is not completely explained by variation in the fraction of workers reemployed, the almost-significant correlation does suggest that this is not a trivial problem. 
STATETREND, STATESHOCK, INDTREND, INDSHOCK). This specification may be viewed in two ways. First, it can be viewed as the reduced-form, differenced version of a model that relates wage levels to local demand conditions and employment history. Alternatively, the specification can simply be viewed as an exploratory attempt to identify those workers most hurt by job displacement. Our own interpretation leans more toward the first view, but we think the exercise is interesting from either perspective.

We should note, however, that certain other factors might also be included in the analysis. In particular, table 1 showed that the mean reduction in weekly wages varied substantially across survey years. Further, it is likely that displaced workers gradually regain some of their lost earnings so that one might also want to control for the number of years between the displacement and the survey. Omitting these factors from the analysis would potentially lead to distorted inferences on interindustry variation if industries differ in the distribution of their displaced workers across survey years and displacement years. Yet while we wish to control for year of survey and year of displacement, computational considerations dictate that we not allow the effect of these factors to differ by industry. ${ }^{12}$

After some experimentation, we settled on the following procedure as a compromise. We first computed the following regression:

$$
\left[\log \left(\text { wage }_{\text {postdisp }}\right)-\log \left(\text { wage }_{\text {predisp }}\right)\right]=X_{i}^{\prime} \beta+Z_{i}^{\prime} \gamma+\zeta_{i},
$$

where $X_{i}$ are the human capital and local market variables described in the Appendix, and $Z_{i}$ are a set of 14 dummy variables for year of survey and year of displacement ( 3 survey years $\times 5$ displacement years per survey-one left-out group). The coefficients on these dummy variables estimate the partial effect on wage reductions of being in various survey year/displacement year cells, relative to a worker who was displaced in 1987 and surveyed in 1988. We then computed

$$
\text { WAGECHANGE }=\left[\log \left(\text { wage }_{\text {postdisp }}\right)-\log \left(\text { wage }_{\text {predisp }}\right)\right]-Z_{i} \hat{\gamma}
$$

With this procedure, WAGECHANGE adjusts the average wage change for any displacement year/survey year cell to be the same as that of the

${ }^{12}$ In what follows, we estimate wage-loss regressions for individual industries that have as few as 20 observations. Since we already have 11 regressors in the model and properly controlling for the effects of survey year and displacement year would add at least five more regressors, it was not feasible to allow the latter effects to differ across industries. 
displaced-in-1987/surveyed-in-1988 cell, save for intercell variation that can be explained by work history and local labor market conditions. ${ }^{13}$

This adjustment is potentially important because there is some interindustry variation in the temporal pattern of displacements. A relatively large fraction of the displacements in construction and manufacturing industries occurred in the 1979-84 period when wage reductions for displaced workers were generally high. Therefore, without this correction, we might presume that these industries were "high wage loss" industries merely because their displacements happened to occur in years in which displacement costs were generally high. In addition, this procedure adjusts for interindustry variation in the length of time between year of displacement and year of survey. It is of course possible that the effects of survey year and displacement year differ by industry but, as we stated above, allowing for such differences proved computationally intractable. ${ }^{14}$

\section{An Empirical Strategy}

This section outlines and motivates our empirical strategy for assessing interindustry variation in the size and determinants of the costs of job displacement. Our basic tool of analysis will be industry-specific regressions of WAGECHANGE on an intercept and the measures of work history and local labor conditions. We initially estimate these regressions with OLS, but industry-specific OLS regressions are imprecisely estimated, particularly for the smaller industries. The imprecision of OLS leads us to the use of an empirical Bayes procedure that generates substantially more precise estimates. The empirical Bayes procedure requires only mildly stronger assumptions than OLS, and, while not common in econometrics,

${ }^{13}$ The survey year/displacement year dummies were estimated as follows (displacement year/survey year: estimated dummy): 79/84: -.087; 80/84: -.035; 81/ 84: $-.016 ; 82 / 84:-.029 ; 83 / 84: .023 ; 81 / 86: .050 ; 82 / 86: .016 ; 83 / 86: .030 ; 84 /$ 86: $-.023 ; 85 / 86: .004 ; 83 / 88: .056 ; 84 / 88: .001 ; 85 / 88:-.004$; and 86/88: -.077 .

${ }^{14}$ There is an additional reason for our limited treatment of survey-year and displacement-year effects. One of the reasons why these effects are potentially of interest is that they might provide information on the rate at which displaced workers gain back some of their lost earnings. Since we only have one postdisplacement observation in the DWS, any inference on such adjustment must be based on cross-sectional comparisons across workers with varying degrees of postdisplacement experience. This is unfortunate because the impact of recall bias means that, for example, the current experience of workers displaced 5 years ago is likely to be a poor predictor of what will happen in 4 years to those currently 1 year past their displacement. The basic reason for this recall bias is that those displaced workers who actually report the displacement 5 years after the fact tend disproportionately to be those workers who have had the most difficult time adjusting to the event (Akerlof and Yellen 1985). In contrast, almost everyone reports a displacement that happened only a year ago, regardless of whether or not the displacement was costly. As a result, cross-sectional comparisons tend to overstate the durability of displacement-induced wage reductions. 
such methods have found wide application in applied statistics (see Morris [1983] for a survey).

Before computing the regressions, we deviated the continuous regressors (all except PLANTCLOSED) from the all-industry mean so that each industry's intercept is the model's prediction of WAGECHANGE for someone with characteristics of the all-industry mean who was displaced in a mass layoff $($ PLANTCLOSED $=0) .{ }^{15}$ After this reparameterization, we consider $T$ regression models of the form

$$
\begin{gathered}
Y_{i}=X_{i} \beta_{i}+\varepsilon_{i}, \quad i=1, \ldots, T, \\
\beta_{i}=\left(\beta_{i 1}, \ldots, \beta_{i 11}\right)^{\prime}, \quad \varepsilon_{i}=\left(\varepsilon_{i 1}, \ldots, \varepsilon_{i n_{i}}\right)^{\prime}, \\
{\left[\varepsilon_{i} \mid \sigma_{i}^{2}\right] \sim N_{n_{i}}\left(0, \sigma_{i}^{2} I\right),}
\end{gathered}
$$

and

$$
\left[\varepsilon_{1} \mid \sigma_{i}^{2}\right], \ldots,\left[\varepsilon_{T} \mid \sigma_{T}^{2}\right] \text { are independent. }
$$

For our purposes, $i$ denotes an industry so that $T=10$ for the one-digit case and 50 for the two-digit case; $n_{i}$ is the number of observations per industry, which ranges from 22 to several thousand in our data.

We consider two approaches to estimating these sets of regressions. The first is ordinary least squares based on $(1 \mathrm{a}-1 \mathrm{~d})$, so that

$$
\left[\hat{\beta}_{i}^{\text {ols }} \mid \beta_{i}, \sigma_{i}^{2}\right] \sim N\left(\beta_{i}, \sigma_{i}^{2}\left(X_{i}^{\prime} X_{i}\right)^{-1}\right),
$$

where

$$
\hat{\beta}_{i}^{\text {ols }}=\left(X_{i}^{\prime} X_{i}\right)^{-1} X_{i}^{\prime} Y_{i}
$$

Tables 2 and 3 present interindustry comparisons that are based in part on these OLS regressions. Table 2 reports estimates for all one-digit industries while table 3 reports estimates for selected two-digit industries. ${ }^{16}$

${ }^{15}$ As described in the Appendix, PLANTCLOSED $=1$ if the worker was displaced from an establishment that laid off all workers and shut down completely. In contrast, PLANTCLOSED $=0$ if the worker was laid off from an establishment that continued its operations at a smaller employment scale.

${ }^{16}$ The one-digit industry breakdown is drawn from the Census Bureau's own major industry classification scheme. In the two-digit case, we first created the finest possible concordance between the CPS industry codes and the two-digit standard industrial classification codes used in the CBP. This led to a 65 -industry classification scheme. However, 15 of these industries had less than 10 observations in our data set, so we grouped them with similar industries. Complete details of this procedure are available on request. 
Table 2

Tenure, Experience, and Wage Changes by One-Digit Industry

\begin{tabular}{|c|c|c|c|c|c|}
\hline $\begin{array}{l}\text { One-Digit } \\
\text { Industry }\end{array}$ & $\begin{array}{l}\text { Sample } \\
\text { Size } \\
(1)\end{array}$ & $\begin{array}{l}\text { Mean Change } \\
\text { in Log Wage } \\
(2)\end{array}$ & $\begin{array}{l}\text { OLS } \\
\text { Intercept } \\
\text { (3) }\end{array}$ & $\begin{array}{c}\text { OLS Contrast } \\
\text { for Workers } \\
\text { with } 10 \text { and } 0 \\
\text { Years of } \\
\text { TENURE } \\
(4)\end{array}$ & $\begin{array}{c}\text { OLS Contrast } \\
\text { for Workers } \\
\text { with } 20 \text { and } 0 \\
\text { Years of } \\
\text { EXPERIENCE } \\
\text { (5) }\end{array}$ \\
\hline \multicolumn{6}{|l|}{$\begin{array}{l}\text { Agriculture, } \\
\text { forestry, and }\end{array}$} \\
\hline fishing & 110 & $\begin{array}{l}.003 \\
(.034)\end{array}$ & $\begin{array}{l}-.080 \\
(.085)\end{array}$ & $\begin{array}{l}-.057 \\
(.122)\end{array}$ & $\begin{array}{l}.183 \\
(.159)\end{array}$ \\
\hline Mining & 340 & $\begin{array}{l}-.381 \\
(.028)\end{array}$ & $\begin{array}{l}-.471 \\
(.053)\end{array}$ & $\begin{array}{l}-.186 \\
(.092)\end{array}$ & $\begin{array}{l}-.188 \\
(.149)\end{array}$ \\
\hline Construction & 848 & $\begin{array}{l}-.145 \\
(.015)\end{array}$ & $\begin{array}{l}-.152 \\
(.028)\end{array}$ & $\begin{array}{l}-.060 \\
(.052)\end{array}$ & $\begin{array}{l}.082 \\
(.066)\end{array}$ \\
\hline $\begin{array}{l}\text { Durable } \\
\text { manufacturing }\end{array}$ & 2410 & $\begin{array}{c}-.130 \\
(.009)\end{array}$ & $\begin{array}{c}-.169 \\
(.015)\end{array}$ & $\begin{array}{c}-.189 \\
(.025)\end{array}$ & $\begin{array}{c}-.082 \\
(.038)\end{array}$ \\
\hline $\begin{array}{l}\text { Nondurable } \\
\text { manufacturing }\end{array}$ & 471 & $\begin{array}{c}-.151 \\
(.019)\end{array}$ & $\begin{array}{c}-.163 \\
(.032)\end{array}$ & $\begin{array}{c}-.179 \\
(.055)\end{array}$ & $\begin{array}{c}-.041 \\
(.091)\end{array}$ \\
\hline Transportation & 375 & $\begin{array}{l}-.088 \\
(.022)\end{array}$ & $\begin{array}{l}-.093 \\
(.044)\end{array}$ & $\begin{array}{l}-.028 \\
(.067)\end{array}$ & $\begin{array}{l}-.048 \\
(.100)\end{array}$ \\
\hline Wholesale trade & 521 & $\begin{array}{c}-.052 \\
(.017)\end{array}$ & $\begin{array}{c}-.103 \\
(.036)\end{array}$ & $\begin{array}{c}-.082 \\
(.054)\end{array}$ & $\begin{array}{c}-.223 \\
(.069)\end{array}$ \\
\hline Retail trade & 114 & $\begin{array}{l}-.105 \\
(.038)\end{array}$ & $\begin{array}{l}-.125 \\
(.092)\end{array}$ & $\begin{array}{l}-.128 \\
(.135)\end{array}$ & $\begin{array}{l}.075 \\
(.072)\end{array}$ \\
\hline $\begin{array}{l}\text { Finance, insurance, } \\
\text { real estate }\end{array}$ & 465 & $\begin{array}{c}-.035 \\
(.020)\end{array}$ & $\begin{array}{c}-.153 \\
(.051)\end{array}$ & $\begin{array}{c}-.184 \\
(.071)\end{array}$ & $\begin{array}{c}-.166 \\
(.081)\end{array}$ \\
\hline Service & 180 & $\begin{array}{l}-.009 \\
(.031)\end{array}$ & $\begin{array}{l}.231 \\
(.091)\end{array}$ & $\begin{array}{l}-.025 \\
(.111)\end{array}$ & $\begin{array}{l}-.320 \\
(.141)\end{array}$ \\
\hline
\end{tabular}

NOTES.-Column 1 reports the number of observations with valid information on pre- and postdisplacement wage levels. Column 2 reports the mean change in log real weekly wages for each industry. The change is computed as (log real postdisplacement weekly wage) - (log real predisplacement weekly wage), so that negative numbers correspond to wage reductions. Columns 3-5 are based on ordinary least square (OLS) regressions of WAGECHANGE on TENURE, TENURE2, EXPERIENCE, EXPERIENCE2, EDUCATION, PLANTCLOSED, STATESHOCK, STATETREND, INDSHOCK, and INDTREND. The intercept is the OLS model's prediction of wage reductions for a worker with the characteristics of the all-industry mean. The contrasts of cols. 4 and 5 are simply the model's predictions of the difference in weekly wage change for two workers that are identical except for their levels of TENURE or EXPERIENCE. In each case, the contrast was computed so that negative numbers indicate larger wage reductions for workers with more tenure or experience. Standard errors are in parentheses.

Column 1 of each table shows that there are wide differences in the number of displacements reported in the DWS for each industry. In the one-digit samples of table 2, there are roughly 2,500 observations in the durable manufacturing industry, but only 110 in the agriculture, forestry, and fishing industry. Even wider differences exist among the two-digit industries, where some industries have as few as 22 displaced workers in our sample. These disparities reflect industry differences in both frequency of displacement and industry size. (On the former score, displacements are more frequent in the mining, construction, and manufacturing industries and less frequent in the trade and service industries.) The wide disparity in sample sizes 
Table 3

Tenure, Experience, and Wage Changes by Selected Two-Digit Industry

\begin{tabular}{|c|c|c|c|c|c|}
\hline $\begin{array}{l}\text { Selected Two-Digit } \\
\text { Industries }\end{array}$ & $\begin{array}{l}\text { Sample } \\
\text { Size } \\
(1)\end{array}$ & $\begin{array}{l}\text { Mean Change } \\
\text { in Log Wage } \\
\text { (2) }\end{array}$ & $\begin{array}{c}\text { OLS } \\
\text { Intercept } \\
(3)\end{array}$ & $\begin{array}{l}\text { OLS Contrast } \\
\text { for Workers } \\
\text { with } 10 \text { and } \\
\text { O Years of } \\
\text { TENURE } \\
\text { (4) }\end{array}$ & $\begin{array}{c}\text { OLS } \\
\text { Contrast for } \\
\text { Workers } \\
\text { with } 20 \text { and } \\
\text { O Years of } \\
\text { EXPERIENCE } \\
(5)\end{array}$ \\
\hline $\begin{array}{l}\text { Agriculture, forestry, } \\
\text { and fishing }\end{array}$ & 109 & $\begin{array}{l}.003 \\
(.034)\end{array}$ & $\begin{array}{l}-.086 \\
(.083)\end{array}$ & $\begin{array}{l}-.057 \\
(.122)\end{array}$ & $\begin{array}{l}.183 \\
(.159)\end{array}$ \\
\hline Metal mining & 51 & $\begin{array}{c}-.474 \\
(.083)\end{array}$ & $\begin{array}{r}-.359 \\
(.117)\end{array}$ & $\begin{array}{l}.582 \\
(.287)\end{array}$ & $\begin{array}{c}-.787 \\
(.493)\end{array}$ \\
\hline Coal mining & 81 & $\begin{array}{l}-.350 \\
(.055)\end{array}$ & $\begin{array}{r}-.498 \\
(.119)\end{array}$ & $\begin{array}{c}-.473 \\
(.166)\end{array}$ & $\begin{array}{c}-.484 \\
(.336)\end{array}$ \\
\hline Construction & 848 & $\begin{array}{l}-.147 \\
(.015)\end{array}$ & $\begin{array}{c}-.152 \\
(.028)\end{array}$ & $\begin{array}{l}-.060 \\
(.052)\end{array}$ & $\begin{array}{l}.082 \\
(.067)\end{array}$ \\
\hline Lumber/wood products & 145 & $\begin{array}{r}-.074 \\
(.035)\end{array}$ & $\begin{array}{r}-.163 \\
(.073)\end{array}$ & $\begin{array}{l}-.193 \\
(.109)\end{array}$ & $\begin{array}{c}-.261 \\
(.158)\end{array}$ \\
\hline Printing/publishing & 76 & $\begin{array}{l}.055 \\
(.037)\end{array}$ & $\begin{array}{l}.075 \\
(.106)\end{array}$ & $\begin{array}{l}.086 \\
(.119)\end{array}$ & $\begin{array}{r}-.347 \\
(.175)\end{array}$ \\
\hline Petroleum/coal products & 28 & $\begin{array}{r}-.069 \\
(.099)\end{array}$ & $\begin{array}{l}.094 \\
(.235)\end{array}$ & $\begin{array}{l}.213 \\
(.409)\end{array}$ & $\begin{array}{l}.371 \\
(.589)\end{array}$ \\
\hline Leather products & 28 & $\begin{array}{l}.044 \\
(.064)\end{array}$ & $\begin{array}{l}.158 \\
(.161)\end{array}$ & $\begin{array}{c}-.014 \\
(.212)\end{array}$ & $\begin{array}{l}.095 \\
(.299)\end{array}$ \\
\hline Fabricated metal & 222 & $\begin{array}{r}-.134 \\
(.028)\end{array}$ & $\begin{array}{r}-.163 \\
(.051)\end{array}$ & $\begin{array}{l}-.268 \\
(.082)\end{array}$ & $\begin{array}{l}.129 \\
(.138)\end{array}$ \\
\hline Transport equipment & 298 & $\begin{array}{c}-.191 \\
(.026)\end{array}$ & $\begin{array}{l}-.199 \\
(.044)\end{array}$ & $\begin{array}{l}-.105 \\
(.077)\end{array}$ & $\begin{array}{l}-.231 \\
(.125)\end{array}$ \\
\hline $\begin{array}{l}\text { Instruments } \\
\text { manufacturing }\end{array}$ & 55 & $\begin{array}{c}-.073 \\
(.048)\end{array}$ & $\begin{array}{l}.028 \\
(.103)\end{array}$ & $\begin{array}{l}.337 \\
(.175)\end{array}$ & $\begin{array}{l}.043 \\
(.280)\end{array}$ \\
\hline Trucking/warehousing & 190 & $\begin{array}{l}-.164 \\
(.031)\end{array}$ & $\begin{array}{c}-.134 \\
(.058)\end{array}$ & $\begin{array}{r}-.145 \\
(.085)\end{array}$ & $\begin{array}{l}-.106 \\
(.151)\end{array}$ \\
\hline Communications & 70 & $\begin{array}{c}-.072 \\
(.053)\end{array}$ & $\begin{array}{l}-.146 \\
(.097)\end{array}$ & $\begin{array}{r}-.072 \\
(.183)\end{array}$ & $\begin{array}{r}-.063 \\
(.246)\end{array}$ \\
\hline $\begin{array}{l}\text { Wholesale trade- } \\
\text { durables }\end{array}$ & 228 & $\begin{array}{c}-.059 \\
(.028)\end{array}$ & $\begin{array}{l}-.126 \\
(.065)\end{array}$ & $\begin{array}{c}-.044 \\
(.093)\end{array}$ & $\begin{array}{l}-.002 \\
(.134)\end{array}$ \\
\hline $\begin{array}{l}\text { Car dealers/service } \\
\text { stations }\end{array}$ & 182 & $\begin{array}{c}-.051 \\
(.031)\end{array}$ & $\begin{array}{l}-.001 \\
(.064)\end{array}$ & $\begin{array}{l}.074 \\
(.106)\end{array}$ & $\begin{array}{r}-.169 \\
(.128)\end{array}$ \\
\hline Apparel stores & 22 & $\begin{array}{c}-.008 \\
(.085)\end{array}$ & $\begin{array}{l}-.256 \\
(.356)\end{array}$ & $\begin{array}{c}-.229 \\
(.338)\end{array}$ & $\begin{array}{c}-.485 \\
(.331)\end{array}$ \\
\hline Banks, securities brokers & 38 & $\begin{array}{r}-.068 \\
(.057)\end{array}$ & $\begin{array}{r}-.171 \\
(.189)\end{array}$ & $\begin{array}{r}-.034 \\
(.285)\end{array}$ & $\begin{array}{r}-.199 \\
(.347)\end{array}$ \\
\hline Insurance & 30 & $\begin{array}{r}-.039 \\
(.072)\end{array}$ & $\begin{array}{c}-.246 \\
(.184)\end{array}$ & $\begin{array}{r}-.109 \\
(.267)\end{array}$ & $\begin{array}{r}-.566 \\
(.417)\end{array}$ \\
\hline Business services & 191 & $\begin{array}{c}-.012 \\
(.032)\end{array}$ & $\begin{array}{c}-.051 \\
(.121)\end{array}$ & $\begin{array}{l}-.148 \\
(.111)\end{array}$ & $\begin{array}{l}-.173 \\
(.139)\end{array}$ \\
\hline Auto repair & 130 & $\begin{array}{c}-.004 \\
(.031)\end{array}$ & $\begin{array}{l}-.046 \\
(.094)\end{array}$ & $\begin{array}{c}-.083 \\
(.126)\end{array}$ & $\begin{array}{c}-.143 \\
(.122)\end{array}$ \\
\hline Health services & 35 & $\begin{array}{l}.013 \\
(.082)\end{array}$ & $\begin{array}{l}.646 \\
(.427)\end{array}$ & $\begin{array}{l}.398 \\
(.358)\end{array}$ & $\begin{array}{l}.409 \\
(.448)\end{array}$ \\
\hline
\end{tabular}

NOTES.-Column 1 reports the number of observations with valid information on pre- and postdisplacement wage levels. Column 2 reports the mean change in log real weekly wages for each industry. The change is computed as (log real postdisplacement weekly wage) - (log real predisplacement weekly wage), so that negative numbers correspond to wage reductions. Columns 3-5 are based on ordinary least squares (OLS) regressions of WAGECHANGE on TENURE, TENURE2, EXPERIENCE, EXPERIENCE2, EDUCATION, PLANTCLOSED, STATESHOCK, STATETREND, INDSHOCK, and INDTREND. The intercept is the OLS model's prediction of wage reductions for a worker with the characteristics of the all-industry mean. The contrasts of cols. 4 and 5 are simply the model's predictions of the difference in weekly wage change for two workers that are identical except for their levels of TENURE or EXPERIENCE. In each case, the contrast was computed so that negative numbers indicate larger wage reductions for workers with more tenure or experience. Standard errors are in parentheses. 
causes the estimated mean wage changes of column 2 to be estimated much more precisely for some industries than for others. At the two-digit level for example, the standard error of the mean for the "transportation equipment manufacturing" industry is only .026 , while the standard error for the "apparel stores" industry is .085 .

More substantively, column 2 of tables 2 and 3 shows wide disparities in wage change by industry. Among the one-digit industries, mean wage changes range from -.381 for mining to .003 for agriculture. And among two-digit industries, estimated mean wage changes range from -.474 for metal mining to .013 for health services. While sampling error overstates the range of interindustry variation, an $F$-test overwhelmingly rejects the hypothesis that mean wage changes are the same across industries at either the one-digit or two-digit levels of aggregation.

To some extent, the variation in mean wage changes reflects interindustry variation in observable factors that affect the cost of displacement. For example, some industries' displacements are heavily concentrated in the 1984 sample, when displacement costs were high. Similarly, some industries' displaced workers had higher average tenure and experience than did displaced workers in other industries. In an effort to abstract from these confounding factors, column 3 reports the estimated intercept from the OLS regressions, which, given our reparameterization, reports each model's prediction of WAGECHANGE for a worker with the characteristics of the all-industry mean. Comparison of columns 2 and 3 shows that controlling for these observables does not greatly affect the relative estimates of the costs of displacement. In fact, controlling for these factors in the one-digit case moves mining and service even further to the periphery. ${ }^{17}$

Columns 4 and 5 of tables 2 and 3 present contrasts of workers with various levels of experience and tenure based on the OLS WAGECHANGE regressions. These contrasts are the OLS prediction of the difference in wage reductions for workers that are observationally identical except for their different levels of tenure or experience. For example, column 3 reports that, for most industries, workers with 10 years of predisplacement tenure have substantially larger wage reductions than do similar workers with 0 years of predisplacement tenure. Examination of tables 2 and 3 shows wide differences across industries in the role of work history in determining the size of displacement-induced wage reductions. In the one-digit case, hightenure workers in the durable manufacturing industry lose much more than do their low-tenure counterparts while, in contrast, tenure plays only a modest role in the service industry. Among two-digit industries, estimates of the effect of 20 years of EXPERIENCE range from - .787 for the metal mining industry to .409 for the health services industry. Again, while sam-

${ }^{17}$ The complete regressions on which this and the following tables are based are available on request. 
pling error overstates the range of variation, $F$-tests strongly reject the hypotheses that the effect of tenure or experience are the same across industries.

An unfortunate feature of the OLS estimates of tables 2 and 3 is that they are extremely imprecise, particularly for the smaller industries. The industryspecific standard errors of some parameters for smaller industries are up to 10 times as large as the standard errors of the corresponding parameters estimated from a pooled regression. Similarly, the industry-specific parameters are often of unbelievable sign or magnitude, including occasional estimates of very large positive effects of predisplacement job tenure on WAGECHANGE. This imprecision is really not surprising given that our estimates of industry means were often imprecise themselves, and we are now estimating regressions with 11 independent variables instead of one.

In summary, we draw three conclusions from tables 2 and 3. First, there are important differences in the average cost of displacement across industries regardless of whether we control for observable factors. Second, work history strongly affects the size of displacement-induced wage reductions in some industries, but not others. And third, there are not enough data for precise estimates in some industries, particularly in the two-digit case. As always, the only way to improve on the precision of estimates is to add valid information. Since we are currently unable to extend the data set, the only type of information that we can add to the model is in the form of cross-industry restrictions on the parameter estimates. These considerations lead us to the use of an empirical Bayes estimator that we will now describe.

Note that the OLS approach of equation (2) assumes that parameter estimates for one industry tell us nothing about the likely true parameter values for any other industry. While this is a standard, conservative assumption, it seems unnecessarily restrictive to us. Therefore, our second approach takes an empirical bayesian approach and assumes that the true parameter values for the individual industries are related. In particular, the empirical Bayes model is obtained by assuming that $\beta_{i}$ has a normal prior distribution of the form

$$
\left[\beta_{i} \mid \Theta, \Lambda\right] \sim N(\Theta, \Lambda) .
$$

We follow the statistical literature and refer to this as the assumption of exchangeability. Essentially, exchangeability means that there is some centralized point (or vector) around which the individual industry parameters are likely to be normally distributed. ${ }^{18}$

${ }^{18}$ The assumption embodied in eq. (3) is actually a special case of exchangeability. In particular, the variables need only be from some common distribution, although the normal distribution leads to a more tractable estimator. In general, a vector of random variables $\left(X_{1}, X_{2}, \ldots, X_{n}\right)$ is said to be exchangeable if permuting the random variables does not change the joint distribution of the vector. 
Some examples illustrate the basic idea behind the exchangeability assumption. Suppose that you wished to estimate state-specific unemployment rates on the basis of a sample of 2,000 individuals scattered across the country. There are obviously not enough data to obtain precise estimates for each state individually. However, it would be reasonable to suppose that the distribution of unemployment rates across states will be clustered around some central tendency, and in this case exchangeability would be a reasonable assumption. In contrast, suppose that you wanted to estimate the true rates of divorce in Baltimore, teen pregnancy in New York, and unemployment in Chicago and that you had modest samples from the relevant populations. In this instance, there are three parameters to estimate, but there is little reason to believe that these particular parameters will be clustered around some centralized point, and, as a result, the assumption of exchangeability would be violated. In our view, it is reasonable to believe that the parameter vectors in (1) are likely to be clustered around a centralized vector, so we feel comfortable with the assumption embodied in (3). Moreover, we would like to note that exchangeability is a substantially weaker assumption than is the alternative procedure of aggregation, which requires that coefficients be the same across industries.

With the exchangeability assumption in hand, there are several techniques available. The straight Bayesian approach is to specify the hyperparameters $\Theta$ and $\Lambda$ and to use Bayes's rule for estimating the $\beta_{i}$ 's. This leads to the Bayes estimator

$$
\hat{\beta}_{i}^{\text {Bayes }}=D_{i}^{-1}\left(\sigma_{i}^{-2} X_{i}^{\prime} X_{i} \hat{\beta}_{i}^{\text {ols }}+\Lambda^{-1} \Theta\right),
$$

where

$$
D_{i}=\sigma_{i}^{-2} X_{i}^{\prime} X_{i}+\Lambda^{-1}
$$

Of course, this estimator is a weighted average of the OLS estimate and the assumed prior mean where the weights are the estimated variance of the OLS estimate and the assumed prior variance.

We eschew a straight Bayesian approach because assumptions about $\Theta$ and $\Lambda$ would be inherently arbitrary, particularly for $\Lambda$. Rather, we adopt an empirical Bayes method (hereafter referred to as the EB method) that allows $\Theta$ and $\Lambda$ to be estimated directly from the interindustry distribution of the OLS parameters. In particular, we arrive at an initial estimate of $\Theta$ via

$$
\Theta=\left[\sum_{i=1}^{T} \frac{1}{\hat{\sigma}_{i}^{2}} X_{i}^{\prime} X_{i}\right]^{-1}\left[\sum_{i=1}^{T} \frac{1}{\hat{\sigma}_{i}^{2}} X_{i}^{\prime} Y_{i}\right]
$$


which is essentially a weighted average of the industry-specific OLS estimates, where the weights are inversely related to the parameter's estimated variance. With this initial estimate of $\Theta$ in hand, we then proceed to estimate $\Theta$ and $\Lambda$ with an iterative procedure.

While one can in principal allow for completely general forms for $\Lambda$, this proved computationally intractable in our data. ${ }^{19}$ Therefore, we follow Blattberg and George (1991) and restrict the off-diagonal elements of $\Lambda$ to be zero so that $\Lambda=\operatorname{diag}\left(\lambda_{1}, \ldots, \lambda_{j}, \ldots, \lambda_{11}\right)$, which amounts to assuming no prior covariance across the coefficients. ${ }^{20}$ To estimate the $\lambda_{j}$ 's we proceed as follows. Note that, given $\beta_{i j}$, the conditional distribution of $\hat{\beta}_{i j}$ is $N\left(\beta_{i j}, \sigma_{i}^{2} a_{i j}\right),{ }^{21}$ where $\beta_{i j}$ is the $j$ th coefficient in the $i$ th regression, $\sigma_{i}^{2}$ is the error variance in the $i$ th regression, and $a_{i j}$ is the $j$ th diagonal element of the matrix $\left(X_{i}^{\prime} X_{i}\right)^{-1}$. By the exchangeability assumption, the $\beta_{i j}$ 's are clustered around the common value $\Theta_{j}$; that is, $\beta_{i j} \sim N\left(\Theta_{j}, \lambda_{j}\right)$. It follows that $\hat{\beta}_{i j}$ must also cluster around $\Theta_{j}$, with marginal distribution $\hat{\beta}_{i j} \sim N\left(\Theta_{j}, \lambda_{j}+\sigma_{i}^{2} a_{i j}\right)$. This implies that $E\left(\hat{\beta}_{i j}-\Theta_{j}\right)^{2}=\lambda_{j}+\sigma_{i}^{2} a_{i j}$, so that $\left[\left(\hat{\beta}_{i j}-\hat{\Theta}_{j}\right)^{2}-\hat{\sigma}_{i}^{2} a_{i j}\right]^{+}$is a suitable estimate for $\lambda_{j}$. The positive part is taken because $\lambda_{j}$ must be positive. We estimate $\hat{\lambda}_{j}$ by averaging these estimates over $i=1,2, \ldots, T$ and by adjusting for loss in degrees of freedom due to estimating $\Theta_{j}$ so that

$$
\hat{\lambda}_{j}=\frac{1}{T-1} \sum_{i=1}^{T}\left[\left(\hat{\beta}_{i j}-\hat{\Theta}_{j}\right)^{2}-\hat{\sigma}_{i}^{2} a_{i j}\right]^{+} .
$$

We then reestimate the $\beta_{i}$ 's with (4) and reestimate each element of $\Theta$ with

$$
\hat{\Theta}_{j}=\left[\sum_{i=1}^{T}\left(\frac{1}{\hat{\sigma}_{i}^{2}}\left(X_{i}^{\prime} X_{i}\right)_{j}+\hat{\lambda}_{j}^{-1}\right)\right]^{-1}\left[\sum_{i=1}^{T}\left(\frac{1}{\hat{\sigma}_{i}^{2}}\left(X_{i}^{\prime} Y_{i}\right)_{j}+\hat{\lambda}_{j}^{-1} \hat{\beta}_{i j}\right)\right] .
$$

Note that calculation of (4) requires estimates of (6) and (7), that (6) requires estimates of ( 7$)$ and (4), and so on, so that solutions or $\Theta, \Lambda$, and the $\beta_{i}$ 's must be solved iteratively. This never required more than 10 it-

${ }^{19}$ This is a common problem with this class of estimator.

${ }^{20}$ We were not entirely happy with this assumption, as it is easy to imagine that there might be covariance between parameters. For example, one might imagine that industries with large, positive linear terms in tenure might also have offsettingly large, negative quadratic terms. We experimented with a Gibbs sampler approach that allowed for an arbitrary prior covariance structure, but this actually led to reduced estimator performance. As a result, we feel that the procedure that we report here is the best feasible estimator.

${ }^{21}$ Note that this is a conditional distribution because $\beta_{i j}$ is treated as a random variable in this scheme. 
erations in our data. With solutions to (4), (6), and (7) in hand, the estimated variance of the posterior distribution of the $\beta_{i}$ 's is computed as

$$
\operatorname{var}\left(\beta_{i}^{\mathrm{EB}}\right)=\left\{\hat{\Lambda}^{-1}+\left[\hat{\sigma}_{i}^{2}\left(X_{i}^{\prime} X_{i}\right)^{-1}\right]^{-1}\right\}^{-1} .
$$

Note that the estimated variance of the empirical Bayes estimator is smaller than the variance of the OLS estimator by construction. Of course, the increased precision is a result of the increased information introduced into the model. ${ }^{22}$

We think it worth pausing to further motivate this procedure. Improving estimators requires adding valid information, not techniques. In the case at hand, the information we add is that individual industry parameter vectors are likely to be clustered around some centralized vector (i.e., the exchangeability assumption). It is exactly this information that might lead one to aggregate different industries - anyone would do this if there were several industries and only a few observations on each. The fact that this is regarded as reasonable procedure is evidence for the validity of the exchangeability assumption. Yet there are two reasons why we prefer the Empirical Bayes procedure to the procedure of aggregation. First, aggregation does not correctly represent our prior information-we believe parameters should be similar across industries, but not necessarily equal. Second, when the parameters are different, aggregation can give distorted estimates for unusual industries.

In contrast, the empirical Bayes procedure used here has several advantages. First, the assumptions more closely represent the prior information; we believe parameters to be similar but not equal. Second, if the data indicate that a particular industry parameter is different, then our methods will pick up the difference. Indeed, in the extreme case where all industries are significantly different, our estimated prior variance will be very high, and the estimates will reduce to OLS separately for each industry. Conversely, if the data indicate that a parameter is nearly the same across all industries, exactly the case where aggregation is valid, then our estimated prior variance will be very low, and the estimates will reduce to the aggregated OLS model. Third, experience has shown that this class of models performs very well in similar situations (for examples, see survey by Morris [1983]). ${ }^{23}$

This particular technique was found to be quite useful in a recent study of supermarket sales (Blattberg and George 1991), and similar techniques

${ }^{22}$ This is exactly the formula for the variance of the posterior distribution in standard Bayesian analysis. The departure from Bayesian methodology is that the prior variance is estimated from the data.

${ }^{23}$ One frequentist model that bears some resemblance to these methods is the random effects model for panel data. In that model, the data dictate the relative weights to be put on the within-unit and between-unit variation. 
have found wide application both in the statistical literature and in other applied fields. ${ }^{2+}$ Therefore, there is nothing new in our techniques. However, to our knowledge there are few applications of this or related techniques in the economics literature (one exception is Zellner and Hong [1989]).

In the remainder of this section we compare the performance of the empirical Bayes estimator with the OLS estimators of equation (1). ${ }^{25}$ In particular, we estimated both the OLS and EB models on the 1984 and 1986 data alone and then used these estimates to predict WAGECHANGE outcomes in the 1988 sample. For each industry, we then computed the ratio of EB mean squared error to OLS mean squared error, and called the resultant number RATIO. More specifically,

$$
\text { RATIO }=\frac{\sum_{j=1}^{n_{i}^{88}}\left(X_{i j} \hat{\beta}_{i}^{\mathrm{EB}}-Y_{i j}\right)^{2}}{\sum_{j=1}^{n_{i}^{8}}\left(X_{i j} \hat{\beta}_{i}^{\mathrm{OLS}}-Y_{i j}\right)^{2}},
$$

where the coefficients are estimated on the 1984 and 1986 samples alone and the summations are taken over the 1988 sample. Figures 1 and 2 display industry values of RATIO plotted against the number of observations for

${ }^{24} \mathrm{~A}$ well-known application of empirical Bayes techniques is in the problem of forecasting season-long baseball averages on the basis of a batter's performance in the first month of the season. As it turns out, first-month averages are rather poor predictors of rest-of-season averages. It has been shown that estimators that shrink individual batting averages toward the group mean do a much better job of predicting rest-of-season averages (evaluated by mean-squared-error criteria) than do the more standard frequentist techniques. Another well-known application is that of Fay and Herriot (1979). In the mid-1970s, the Census Bureau was asked to estimate the mean income level of every municipality in the country, something it had not anticipated in the design of the 1970 Census. Therefore, the Census had very small income samples for smaller towns. Instead of accepting the noisy estimates, and instead of substituting countywide estimates for small towns, the Census used empirical Bayes techniques that essentially took weighted averages of county and town estimates where the weights were related to the precision of each estimate. Validation studies demonstrated this to be a superior procedure.

${ }^{25}$ We earlier criticized industry-specific OLS estimates because (1) the parameter estimates were too imprecise and because (2) the parameter estimates were often of implausible sign or magnitude. By construction, the shrinkage estimator improves on point 2 because it shrinks industry-specific OLS estimates toward the all-industry mean, which is where our notions of plausible coefficients presumably originated. The EB estimator will also estimate standard errors that are typically smaller than analogous OLS standard errors, so that the estimators are more "precise." Of course EB standard errors are valid only if the exchangeability assumption is correct. Therefore, we view these considerations as a relatively weak basis on which to prefer EB estimates to OLS estimates. 


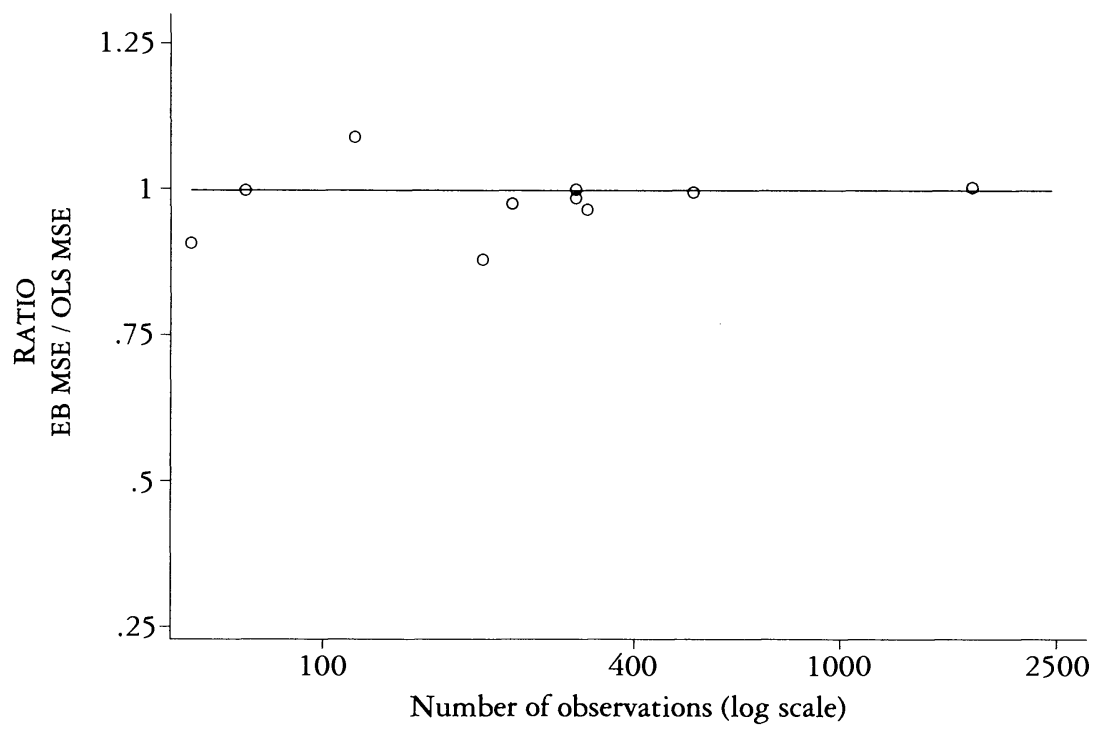

FIG. 1.-Ten-industry sample

that industry in the 1984/1986 sample (in log scale). Figure 1 displays the one-digit results while figure 2 displays the two-digit results. Most of the advantages are concentrated in the small industries where the EB method shrinks the extremely noisy industry-specific estimates toward the

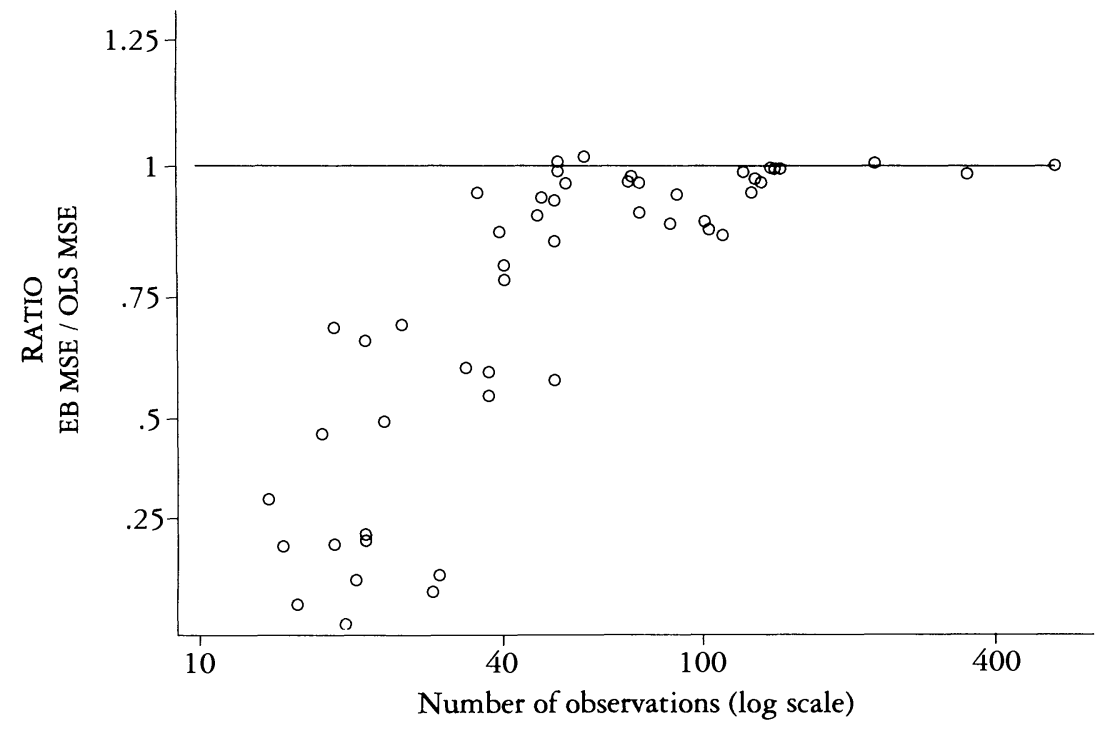

FIG. 2.-Fifty-industry sample 
relatively precisely measured all-industry estimates. In some of the smallest industries, the OLS mean squared error was over 10 times that of the EB mean squared error. Conversely, the EB method offers only limited improvements over OLS for the larger industries. In these cases, the EB method tends to leave the individual industry parameters alone because they are estimated fairly precisely. However, it is clear from both figures that the EB estimator never does much worse than OLS and often does much better. ${ }^{26}$ As a result, we believe the empirical Bayes estimator to be the preferred method. The next section presents our analysis based on this procedure.

\section{Interindustry Variation in the Costs of Displacement}

Tables 4 and 5 present our analysis of interindustry variation in the costs of job displacement based on the empirical Bayes technique of the previous section. These tables are the direct analogues to the OLS results of tables 2 and 3. While the EB estimates of tables 4 and 5 are broadly similar to the OLS estimates of tables 2 and 3, there are two main differences. First, there is less interindustry variation in any given EB parameter, particularly for the two-digit case. Second, the estimated EB standard errors are smaller than their OLS counterparts, a direct result of the increased information added to the model. Again, the increase in precision is most notable for the smaller industries.

We initially motivated our study by pointing out widely held beliefs on the relative importance of the worker/firm relationship in the construction and durable manufacturing industries. The analysis of table 4 provides both support and contradictions for these beliefs. On one hand, there is a particularly weak relationship between work history and WAGECHANGE in the construction industry, which seems to support the view that the employment relationship is of little importance in that industry. However, the mean WAGECHANGE in this industry is right in line with the change for all industries. As a result, it does not appear that displacement is any less costly for construction workers than for similar workers in other industries.

The most unusual industries in table 4 are the mining and service industries, which have very large and very small wage reductions, respectively. These disparities may be due to a combination of unionization (high in mining, low in service) and compensating wage differentials (high in mining, low in service). Alternatively, there may be something about the employment relationship in these industries that is fundamentally different. Unfortunately, there is very little that we can do to assess either of these hypotheses with the DWS data. The next section makes an attempt to sort

${ }^{26}$ We obtained similar results when we used 1984 and 1988 to predict 1986 results and when we used 1986 and 1988 to predict 1984 results. 
these issues out by matching external data on industry characteristics to the industry features reported here.

As expected, the two-digit analysis of table 5 reports greater interindustry variation in these measures of the costs of job displacement. The estimated wage reduction for a standardized worker ranges from -.455 in the petroleum and gas extraction industry to .032 in the leather products manufacturing industry. While this interindustry variation is less than that suggested by the OLS analysis of table 3 , it is still substantial by any measure. To a large extent, the results on two-digit industries reflect the results for their one-digit parent industries reported in table 4. However, there is substantial variation within one-digit industries. For example, within the mining industry, estimated mean wage reductions range from -.455 for the petroleum and gas extraction industry to -.202 for the non-

Table 4

Empirical Bayes Analysis of TENURE, EXPERIENCE, and WAGECHANGE by One-Digit Industry

\begin{tabular}{|c|c|c|c|}
\hline One-Digit Industry & $\begin{array}{c}\mathrm{EB} \\
\text { Intercept } \\
(1)\end{array}$ & $\begin{array}{l}\text { EB Contrast for } \\
\text { Workers with } \\
10 \text { and O Years } \\
\text { of TENURE } \\
(2)\end{array}$ & $\begin{array}{l}\text { EB Contrast for } \\
\text { Workers with } 20 \\
\text { and O Years of } \\
\text { EXPERIENCE } \\
(3)\end{array}$ \\
\hline \multicolumn{4}{|l|}{ Agriculture, forestry, and } \\
\hline fishing & $\begin{array}{l}-.102 \\
(.045)\end{array}$ & $\begin{array}{c}-.091 \\
(.118)\end{array}$ & $\begin{array}{c}-.014 \\
(.159)\end{array}$ \\
\hline Mining & $\begin{array}{r}-.409 \\
(033)\end{array}$ & $\begin{array}{r}-.117 \\
(.084)\end{array}$ & $\begin{array}{r}-.090 \\
.119)\end{array}$ \\
\hline Construction & $\begin{aligned}-.157 \\
(.066)\end{aligned}$ & $\begin{array}{l}-.075 \\
(.048)\end{array}$ & $\begin{array}{l}.013 \\
(.053)\end{array}$ \\
\hline Durable manufacturing & $\begin{array}{l}-.155 \\
(.013)\end{array}$ & $\begin{array}{l}-.148 \\
(.023)\end{array}$ & $\begin{array}{l}-.097 \\
(.032)\end{array}$ \\
\hline Nondurable manufacturing & $\begin{aligned}-.158 \\
(.024)\end{aligned}$ & $\begin{array}{l}-.114 \\
(.051)\end{array}$ & $\begin{array}{l}-.075 \\
-.074)\end{array}$ \\
\hline Transportation & $\begin{array}{l}-.105 \\
(.029)\end{array}$ & $\begin{array}{l}-.094 \\
(.064)\end{array}$ & $\begin{array}{l}-.054 \\
(.081)\end{array}$ \\
\hline Wholesale trade & $\begin{array}{l}-.098 \\
(.025)\end{array}$ & $\begin{array}{l}-.101 \\
(.051)\end{array}$ & $\begin{array}{l}-.148 \\
(.058)\end{array}$ \\
\hline Retail trade & $\begin{array}{l}-.126 \\
(.049)\end{array}$ & $\begin{array}{l}-.099 \\
(.127)\end{array}$ & $\begin{array}{l}-.054 \\
(.142)\end{array}$ \\
\hline $\begin{array}{l}\text { Finance, insurance, and real } \\
\text { estate }\end{array}$ & $\begin{array}{c}-.111 \\
(.034)\end{array}$ & $\begin{array}{c}-.122 \\
(.067)\end{array}$ & $\begin{array}{c}-.119 \\
(.068)\end{array}$ \\
\hline Service & $\begin{array}{l}.028 \\
(.051)\end{array}$ & $\begin{array}{l}-.102 \\
(.105)\end{array}$ & $\begin{array}{l}-.119 \\
(.123)\end{array}$ \\
\hline
\end{tabular}

NOTES.-Column 1 reports empirical Bayes estimates of the intercept in the WAGECHANGE regression described in the text. Due to the reparameterization, the intercept is the model's prediction of WAGECHANGE for a worker with the characteristics of the all-industry mean. In addition to the intercept, the regressions included TENURE, TENURE2, EXPERIENCE, EXPERIENCE2, EDUCATION, PLANTCLOSED, STATESHOCK, STATETREND, INDSHOCK, and INDTREND. The contrasts of cols. 2 and 3 are simply the model's predictions of the difference in WAGECHANGE for two workers that are similar except for their levels of TENURE or EXPERIENCE. In each case, the contrast was computed so that negative numbers indicate larger wage reductions for workers with more tenure or experience. Standard errors are in parentheses. 


\begin{tabular}{|c|c|c|c|}
\hline Two-Digit Industry & $\begin{array}{c}\mathrm{EB} \\
\text { Intercept } \\
(1)\end{array}$ & $\begin{array}{l}\text { EB Contrast for } \\
\text { Workers with } \\
10 \text { and O Years } \\
\text { of TENURE } \\
\text { (2) }\end{array}$ & $\begin{array}{c}\text { EB Contrast for } \\
\text { Workers with } 20 \\
\text { and O Years of } \\
\text { EXPERIENCE } \\
\text { (3) }\end{array}$ \\
\hline $\begin{array}{l}\text { Agriculture, forestry, } \\
\text { and fishing }\end{array}$ & $\begin{array}{c}-.079 \\
(.062)\end{array}$ & $\begin{array}{c}-.060 \\
(.092)\end{array}$ & $\begin{array}{c}.095 \\
(.131)\end{array}$ \\
\hline Metal mining & $\begin{array}{l}-.309 \\
(.091)\end{array}$ & $\begin{array}{l}.028 \\
(.138)\end{array}$ & $\begin{array}{r}-.158 \\
(.233)\end{array}$ \\
\hline Coal mining & $\begin{array}{c}-.384 \\
(.073)\end{array}$ & $\begin{array}{l}-.305 \\
(.117)\end{array}$ & $\begin{array}{c}-.224 \\
(.181)\end{array}$ \\
\hline Petroleum/gas extraction & $\begin{array}{c}-.455 \\
(.059)\end{array}$ & $\begin{array}{l}-.165 \\
(.109)\end{array}$ & $\begin{array}{c}-.027 \\
(.143)\end{array}$ \\
\hline Nonmetallic mining, excluding fuel & $\begin{array}{l}-.202 \\
(.092)\end{array}$ & $\begin{array}{l}-.134 \\
(.138)\end{array}$ & $\begin{array}{l}-.081 \\
(.249)\end{array}$ \\
\hline Construction & $\begin{array}{r}-.150 \\
(.026)\end{array}$ & $\begin{array}{c}-.063 \\
(.049)\end{array}$ & $\begin{array}{c}.068 \\
(.057)\end{array}$ \\
\hline Food manufacturing & $\begin{array}{l}-.179 \\
(.049)\end{array}$ & $\begin{array}{l}-.178 \\
(.078)\end{array}$ & $\begin{array}{l}-.071 \\
(.103)\end{array}$ \\
\hline Textile mill manufacturing & $\begin{array}{l}-.101 \\
(.067)\end{array}$ & $\begin{array}{l}-.294 \\
(.099)\end{array}$ & $\begin{array}{l}-.094 \\
(.133)\end{array}$ \\
\hline Apparel manufacturing & $\begin{array}{l}-.087 \\
(.068)\end{array}$ & $\begin{array}{l}-.185 \\
(.116)\end{array}$ & $\begin{array}{l}-.120 \\
(.129)\end{array}$ \\
\hline Lumber/wood products & $\begin{array}{c}-.150 \\
(.056)\end{array}$ & $\begin{array}{c}-.183 \\
(.087)\end{array}$ & $\begin{array}{c}-.193 \\
(.111)\end{array}$ \\
\hline Furniture/fixtures & $\begin{array}{c}-.071 \\
(.061)\end{array}$ & $\begin{array}{l}-.063 \\
(.092)\end{array}$ & $\begin{array}{l}-.103 \\
(.117)\end{array}$ \\
\hline Paper and allied products & $\begin{array}{l}-.232 \\
(.081)\end{array}$ & $\begin{array}{c}-.089 \\
(.133)\end{array}$ & $\begin{array}{l}-.029 \\
(.160)\end{array}$ \\
\hline Printing/publishing & $\begin{array}{r}-.034 \\
(.061)\end{array}$ & $\begin{array}{c}-.003 \\
(.091)\end{array}$ & $\begin{array}{c}-.294 \\
(.139)\end{array}$ \\
\hline Chemicals and allied products & $\begin{array}{l}-.163 \\
(.056)\end{array}$ & $\begin{array}{l}-.014 \\
(.102)\end{array}$ & $\begin{array}{l}.045 \\
(.145)\end{array}$ \\
\hline Petroleum and coal products & $\begin{array}{l}-.104 \\
(.097)\end{array}$ & $\begin{array}{l}-.049 \\
(.149)\end{array}$ & $\begin{array}{l}.069 \\
(.222)\end{array}$ \\
\hline Rubber and plastic products & $\begin{array}{l}-.185 \\
(.067)\end{array}$ & $\begin{array}{r}-.162 \\
(.115)\end{array}$ & $\begin{array}{c}-.216 \\
(.151)\end{array}$ \\
\hline Leather products & $\begin{array}{l}.032 \\
(.086)\end{array}$ & $\begin{array}{l}-.117 \\
(.126)\end{array}$ & $\begin{array}{l}-.018 \\
(.154)\end{array}$ \\
\hline Stone, clay, and glass & $\begin{array}{l}-.193 \\
(.062)\end{array}$ & $\begin{array}{l}-.133 \\
(.102)\end{array}$ & $\begin{array}{l}-.152 \\
(.146)\end{array}$ \\
\hline Primary metal & $\begin{array}{l}-.258 \\
(.052)\end{array}$ & $\begin{array}{l}-.228 \\
(.074)\end{array}$ & $\begin{array}{l}.045 \\
(.125)\end{array}$ \\
\hline Fabricated metal & $\begin{array}{r}-.165 \\
(.042)\end{array}$ & $\begin{array}{c}-.227 \\
(.072)\end{array}$ & $\begin{array}{c}.051 \\
(.105)\end{array}$ \\
\hline Machinery, excluding electrical & $\begin{array}{l}-.147 \\
(.028)\end{array}$ & $\begin{array}{l}-.225 \\
(.052)\end{array}$ & $\begin{array}{l}.017 \\
(.073)\end{array}$ \\
\hline Electrical machinery & $\begin{array}{l}-.119 \\
(.052)\end{array}$ & $\begin{array}{l}-.171 \\
(.086)\end{array}$ & $\begin{array}{l}-.063 \\
(.117)\end{array}$ \\
\hline Transport equipment & $\begin{array}{l}-.197 \\
(.039)\end{array}$ & $\begin{array}{l}-.116 \\
(.067)\end{array}$ & $\begin{array}{l}-.189 \\
(.098)\end{array}$ \\
\hline Instruments manufacturing & $\begin{array}{c}-.069 \\
(.069)\end{array}$ & $\begin{array}{c}.069 \\
(.113)\end{array}$ & $\begin{array}{c}-.046 \\
(.157)\end{array}$ \\
\hline Miscellaneous manufactured products & $\begin{array}{l}-.053 \\
(.074)\end{array}$ & $\begin{array}{l}-.252 \\
(.126)\end{array}$ & $\begin{array}{l}-.279 \\
(.141)\end{array}$ \\
\hline Local and interurban transport & $\begin{array}{l}-.237 \\
(.056)\end{array}$ & $\begin{array}{l}-.213 \\
(.102)\end{array}$ & $\begin{array}{l}-.290 \\
(.143)\end{array}$ \\
\hline Trucking and warehousing & $\begin{array}{l}-.151 \\
(.046)\end{array}$ & $\begin{array}{l}-.154 \\
(.072)\end{array}$ & $\begin{array}{r}-.095 \\
(.111)\end{array}$ \\
\hline
\end{tabular}




\begin{tabular}{|c|c|c|c|}
\hline Two-Digit Industry & $\begin{array}{c}\mathrm{EB} \\
\text { Intercept } \\
(1) \\
\end{array}$ & $\begin{array}{c}\text { EB Contrast for } \\
\text { Workers with } \\
10 \text { and O Years } \\
\text { of T'ENURE } \\
\text { (2) }\end{array}$ & $\begin{array}{c}\text { EB Contrast for } \\
\text { Workers with } 20 \\
\text { and O Years of } \\
\text { EXPERIENCE } \\
(3)\end{array}$ \\
\hline Water transportation & $\begin{array}{c}-.219 \\
(.078)\end{array}$ & $\begin{array}{c}-.192 \\
(.127)\end{array}$ & $\begin{array}{c}-.193 \\
(.236)\end{array}$ \\
\hline Air and other transport & $\begin{array}{c}-.095 \\
(.067)\end{array}$ & $\begin{array}{c}-.202 \\
(.117)\end{array}$ & $\begin{array}{l}.113 \\
(.158)\end{array}$ \\
\hline Communications & $\begin{array}{r}-.118 \\
(.070)\end{array}$ & $\begin{array}{r}-.113 \\
(.117)\end{array}$ & $\begin{array}{c}-.079 \\
(.151)\end{array}$ \\
\hline Utilities and sanitary services & $\begin{array}{r}-.116 \\
(.087)\end{array}$ & $\begin{array}{c}-.051 \\
(.140)\end{array}$ & $\begin{array}{c}-.055 \\
(.178)\end{array}$ \\
\hline Wholesale trade-durables & $\begin{array}{c}-.090 \\
(.047)\end{array}$ & $\begin{array}{c}-.063 \\
(.079)\end{array}$ & $\begin{array}{c}-.042 \\
(.106)\end{array}$ \\
\hline Wholesale trade-nondurables & $\begin{array}{r}-.109 \\
(.024)\end{array}$ & $\begin{array}{c}-.034 \\
(.085)\end{array}$ & $\begin{array}{c}-.062 \\
(.118)\end{array}$ \\
\hline Building materials/garden stores & $\begin{array}{r}-.088 \\
(.070)\end{array}$ & $\begin{array}{r}-.172 \\
(.114)\end{array}$ & $\begin{array}{c}-.326 \\
(.149)\end{array}$ \\
\hline Grocery/department stores & $\begin{array}{c}-.173 \\
(.070)\end{array}$ & $\begin{array}{r}-.139 \\
(.105)\end{array}$ & $\begin{array}{r}-.066 \\
(.129)\end{array}$ \\
\hline Car dealers/service stations & $\begin{array}{c}-.049 \\
(.051)\end{array}$ & $\begin{array}{c}-.015 \\
(.087)\end{array}$ & $\begin{array}{c}-.138 \\
(.103)\end{array}$ \\
\hline Apparel stores & $\begin{array}{c}-.142 \\
(.095)\end{array}$ & $\begin{array}{c}-.187 \\
(.139)\end{array}$ & $\begin{array}{c}-.268 \\
(.149)\end{array}$ \\
\hline Restaurants & $\begin{array}{c}-.193 \\
(.065)\end{array}$ & $\begin{array}{c}-.178 \\
(.101)\end{array}$ & $\begin{array}{r}-.132 \\
(.110)\end{array}$ \\
\hline Miscellaneous retail & $\begin{array}{c}-.185 \\
(.066)\end{array}$ & $\begin{array}{c}-.147 \\
(.106)\end{array}$ & $\begin{array}{c}-.357 \\
(.139)\end{array}$ \\
\hline Banks and securities brokers & $\begin{array}{c}-.155 \\
(.089)\end{array}$ & $\begin{array}{c}-.037 \\
(.135)\end{array}$ & $\begin{array}{c}-.210 \\
(.193)\end{array}$ \\
\hline Insurance carriers & $\begin{array}{c}-.124 \\
(.081)\end{array}$ & $\begin{array}{c}-.159 \\
(.129)\end{array}$ & $\begin{array}{c}-.342 \\
(.176)\end{array}$ \\
\hline Real estate & $\begin{array}{r}-.156 \\
(.081)\end{array}$ & $\begin{array}{c}-.152 \\
(.137)\end{array}$ & $\begin{array}{c}.293 \\
(.167)\end{array}$ \\
\hline Hotel and personal services & $\begin{array}{c}-.149 \\
(.087)\end{array}$ & $\begin{array}{c}-.121 \\
(.141)\end{array}$ & $\begin{array}{c}-.065 \\
(.162)\end{array}$ \\
\hline Business services & $\begin{array}{c}-.093 \\
(.067)\end{array}$ & $\begin{array}{c}-.163 \\
(.091)\end{array}$ & $\begin{array}{c}-.149 \\
(.117)\end{array}$ \\
\hline Auto repair & $\begin{array}{c}-.082 \\
(.057)\end{array}$ & $\begin{array}{r}-.096 \\
(.097)\end{array}$ & $\begin{array}{c}-.140 \\
(.099)\end{array}$ \\
\hline Miscellaneous repair & $\begin{array}{c}-.230 \\
(.084)\end{array}$ & $\begin{array}{c}-.279 \\
(.135)\end{array}$ & $\begin{array}{c}-.301 \\
(.161)\end{array}$ \\
\hline Motion picture/amusement & $\begin{array}{r}-.130 \\
(.097)\end{array}$ & $\begin{array}{c}-.130 \\
(.147)\end{array}$ & $\begin{array}{l}.106 \\
(.191)\end{array}$ \\
\hline Health services & $\begin{array}{c}-.051 \\
(.097)\end{array}$ & $\begin{array}{c}-.042 \\
(.152)\end{array}$ & $\begin{array}{r}-.068 \\
(.231)\end{array}$ \\
\hline Miscellaneous professional services & $\begin{array}{r}-.059 \\
(.094)\end{array}$ & $\begin{array}{c}-.141 \\
(.157)\end{array}$ & $\begin{array}{c}-.539 \\
(.246)\end{array}$ \\
\hline Miscellaneous services & $\begin{array}{c}-.072 \\
(.068)\end{array}$ & $\begin{array}{c}-.137 \\
(.096)\end{array}$ & $\begin{array}{c}-.249 \\
(.121)\end{array}$ \\
\hline
\end{tabular}

NOTE.-Column 1 reports empirical Bayes estimates of the intercept in the WAGECHANGE regression described in the text. Due to the reparameterization, the intercept is the model's prediction of WAGECHANGE for a worker with the characteristics of the all-industry mean. In addition to the intercept, the regressions included TENURE, TENURE2, EXPERIENCE, EXPERIENCE2, EDUCATION, PLANTCLOSED, STATESHOCK, STATETREND, INDSHOCK, and INDTREND. The contrasts of cols. 2 and 3 are simply the model's predictions of the difference in WAGECHANGE for two workers that are similar except for their levels of TENURE or EXPERIENCE. In each case, the contrast was computed so that negative numbers indicate larger wage reductions for workers with more tenure or experience. Standard errors are in parentheses. 
metallic mining, excluding fuel industry. Similarly, within-manufacturing wage reductions range from .032 (leather products) to -.258 (primary metal), and within-service wage reductions range from -.051 (health services) to -.230 (miscellaneous repair).

There is also substantial interindustry variation in the relationship between predisplacement work history and subsequent wage reductions. For example, there is a very strong relationship between predisplacement job tenure and WAGECHANGE in the coal mining industry but a very weak relationship in the metal mining industry, even though both are subsumed within mining at the one-digit level. Similarly, tenure has a strong effect in the fabricated metal industry but only a weak effect in the instruments manufacturing industry, even though both are subsumed within manufacturing at the one-digit level.

Our summary reading of these results is as follows. In the three dimensions that we have documented, there is a central tendency around which most industries are closely located. These central tendencies entail wage reductions of $13 \%$, differences in wage reductions of $12 \%$ between workers with 10 and 0 years of predisplacement tenure, and differences of $9 \%$ between workers with 20 and 0 years of predisplacement experience. However, in any of these dimensions, there are a number of industries that deviate significantly from the central tendency. These facts suggest to us that job displacement carries similar costs for workers in most industries but that in some industries displacement is either much more or much less costly. These interindustry differences carry implications for the optimal design of displaced worker assistance programs and for our notions about interindustry differences in the nature of the employment relationship. In order to clarify these implications, the next section attempts to understand why it is that some industries are so different from the central tendency around which most industries are clustered.

\section{Sources of Interindustry Variation}

The purpose of this section is to investigate why it is that the costs of job displacement differ across industries. This investigation is motivated by two considerations. The first is that we would simply like to know why industries differ in the ways that we have documented. The second is that the DWS (and other surveys) lack information on some of the factors that might be expected to affect the costs of job displacement (e.g., union status). Therefore, an industry-by-industry analysis may provide insight into the causes of job displacement costs that is not forthcoming from individual-level analyses.

Our basic approach is to relate the results of table 5 to underlying characteristics of each two-digit industry. We considered four basic hypotheses that might explain interindustry variation. The first hypothesis is that workers displaced from highly unionized industries lose more than similar 
workers displaced from nonunionized industries. ${ }^{27}$ To address this issue, we aggregated Kokkelenberg and Sockell's (1985) information on unionization by detailed industry so as to match up with our two-digit breakdown. ${ }^{28}$ Our second hypothesis is that workers displaced from larger firms lose more than similar workers displaced from small firms. This hypothesis arises naturally from the literature on firm size/wage effects (e.g., Brown and Medoff 1989). To address this issue, we collected information on the firm size of the median male worker in each industry as computed from the May 1983 CPS supplement that asked questions about size of firm and establishment. $^{29}$

Our third hypothesis is that industries differ in the incidence of employerprovided training. Theories of on-the-job training (e.g., Becker 1962) suggest that the incidence of training might effect both the average level of displacement-induced costs and the relationship between those costs and a person's work history. Therefore, we collected industry-by-industry information from the January 1983 CPS supplement that included questions on job training. The CPS supplement distinguishes between several dimensions of on-the-job training, including formal versus informal, current job versus previous job, and whether or not the employer paid for the training. After some experimentation, we found that the measure that best explained our interindustry variation in the costs of displacement was the frequency with which workers had received informal on-the-job training, either on the current or any previous job. Therefore, our industry "training" measure is simply the fraction of workers in each industry that had at some time in the past received informal on-the-job training. ${ }^{30}$

${ }^{27}$ It would naturally be better to analyze the impact of unionization at an individual level, but the DWS unfortunately asks no questions on pre- or postdisplacement unionization. Therefore, an industry-by-industry analysis is the best that can be done with these data. In contrast, the PSID does record information on unionization. Topel (1990) shows that workers displaced from unionized jobs do lose substantially more than do similar workers who do not lose union jobs.

${ }^{28}$ The unionization rates are for 1981, the last year in Kokkelenberg and Sockell's sample. To aggregate their detailed industries to our two-digit industries, we took weighted averages of the detailed industries where the weights were the number of respondents in each industry.

${ }^{29}$ The firm-size information in these data were regrettably aggregated into five relatively coarse groups (e.g., 500-1,000 workers). We used the finer groupings of the U.S. Department of Commerce $(1987 b)$ to estimate the firm size of the median worker within each CPS grouping. This interpolation was done rather crudely, in that we used the economywide figures from Enterprise Statistics to interpolate for each CPS industry. A slightly more accurate method would have been to interpolate on an industry-by-industry basis.

${ }^{30}$ In order to maximize the accuracy of this measure, we computed the fractions including both male and female workers. While the informal training measure described here had the most explanatory power, measures of formal training produced similar results. 
Our final hypothesis is that some industries simply pay more than others, for efficiency wage reasons or some other, unspecified cause. To test this hypothesis, we matched the data on industry wage residuals from Krueger and Summers (1988) to our two-digit industry classification. ${ }^{31}$ These residuals are simply the coefficients on detailed industry dummies in a log wage regression that included a very full set of human capital variables. Although their reading of these data has been somewhat controversial, Krueger and Summers interpret these residuals as measures of the noncompetitive rents associated with each industry, perhaps due to efficiency wage considerations.

Figures 3, 4, and 5 present plots of these industry characteristics against our measures of the costs of job displacements. Figure 3 graphs each of the four characteristics against the empirical Bayes estimate of the intercept that, given our parameterization, is the model's estimate of the wage reduction for a worker with standardized characteristics. The graphs suggest that each of these four characteristics has some ability to explain the interindustry variation but that there is much variation that is left unexplained. For example, it is generally true that highly unionized industries exhibit large displacement-induced wage reductions, yet the industry with the largest estimated wage reduction happens to be one with a very low unionization rate (petroleum and natural gas extraction). Similarly, wage reductions are large for most large-firm industries and small for most small-firm industries, yet several largefirm industries have very small estimated wage reductions. In spite of this heterogeneity, it is somewhat comforting that the relationships between these industry characteristics and the costs of job displacement are generally consistent with common sense. Figures 4 and 5 report analogous plots of industry characteristics against the empirical Bayes estimates of the 10-year tenure and 20-year experience contrasts. The graphs suggest that these characteristics are much less successful at explaining these features of the costs of displacement, as there is no clear relationship in any of the eight plots.

Table 6 presents a somewhat more formal analysis of these relationships by reporting the results of OLS regressions based on the data plotted in figures 3,4 , and $5 .{ }^{32}$ Panel A of table 6 presents regressions of the estimated

${ }^{31}$ When aggregating the detailed industries of Krueger and Summers (1988), we used the sampling weights of Kokkelenberg and Sockell (1985).

${ }^{32}$ While these regressions all use the empirical Bayes coefficients as dependent variables, similar tabulations were obtained with OLS coefficients as dependent variables. The main difference between the two sets of regressions is that the latter regressions were less precisely estimated. This is not surprising as the primary attribute of the empirical Bayes method is that it essentially discards the noisiest OLS estimates. We experimented with several weighted versions of these regressions. In particular we experimented with (1) weights that were inversely related to the 

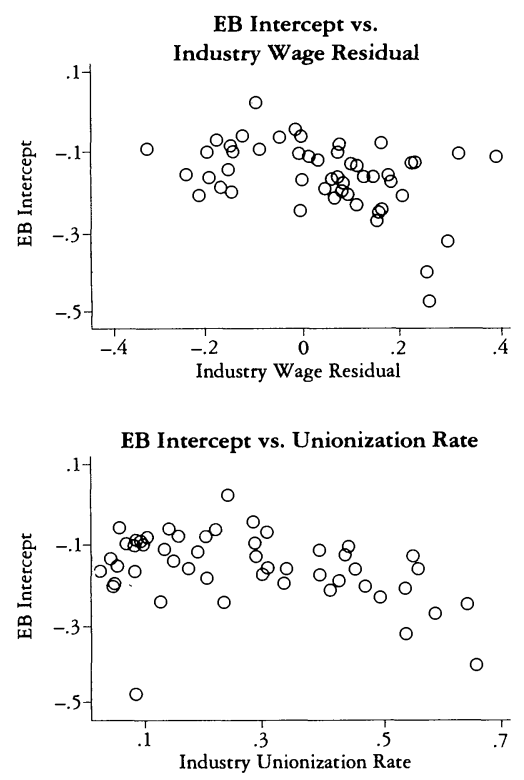

EB Intercept vs. Median Firm Size

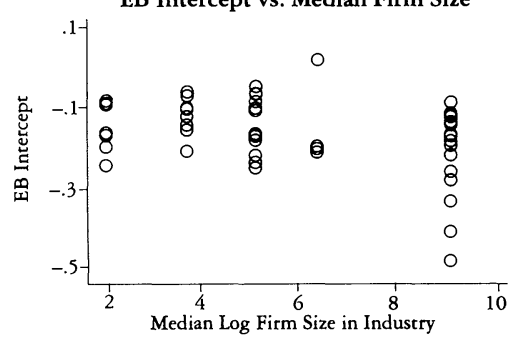

EB Intercept vs. Incidence of

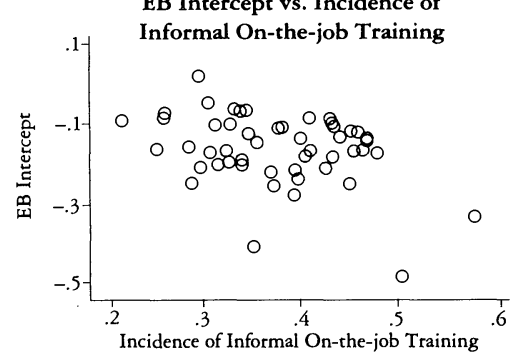

FIG. 3

industry intercept on the underlying industry characteristics. The first four columns present univariate regressions while column 5 includes all four regressors. The first four columns of panel A show that each of these industry characteristics has a statistically significant impact on the industry's average cost of job displacement. For example, the -.225 coefficient on "industry wage residual" means that a worker displaced from an industry with an estimated wage residual of .20 would be expected to have about $10 \%$ larger wage reductions than would a similar worker displaced from an industry with a wage residual of -.20 . Similarly, the -.165 coefficient on "industry unionization rate" means that a worker displaced from an industry that was $60 \%$ unionized would be expected to have a roughly $8 \%$ larger wage reduction than would a similar worker displaced from an industry that was only $10 \%$ unionized. While there is much unexplained variation, the regressions show that these characteristics do explain a significant component of interindustry variation in the costs of displacement. Column 5 reports the results of a regression that includes all four characteristics. Given that we have only 50 industries, it is perhaps not surprising that the results for each regressor become insignificant. The small sample

standard errors of the EB coefficient estimates and (2) a combination of version 1 with various guesses about the true standard error of the interindustry regression. Each of these weighting schemes produced estimates that were quite similar to the OLS regressions reported in table 6. 

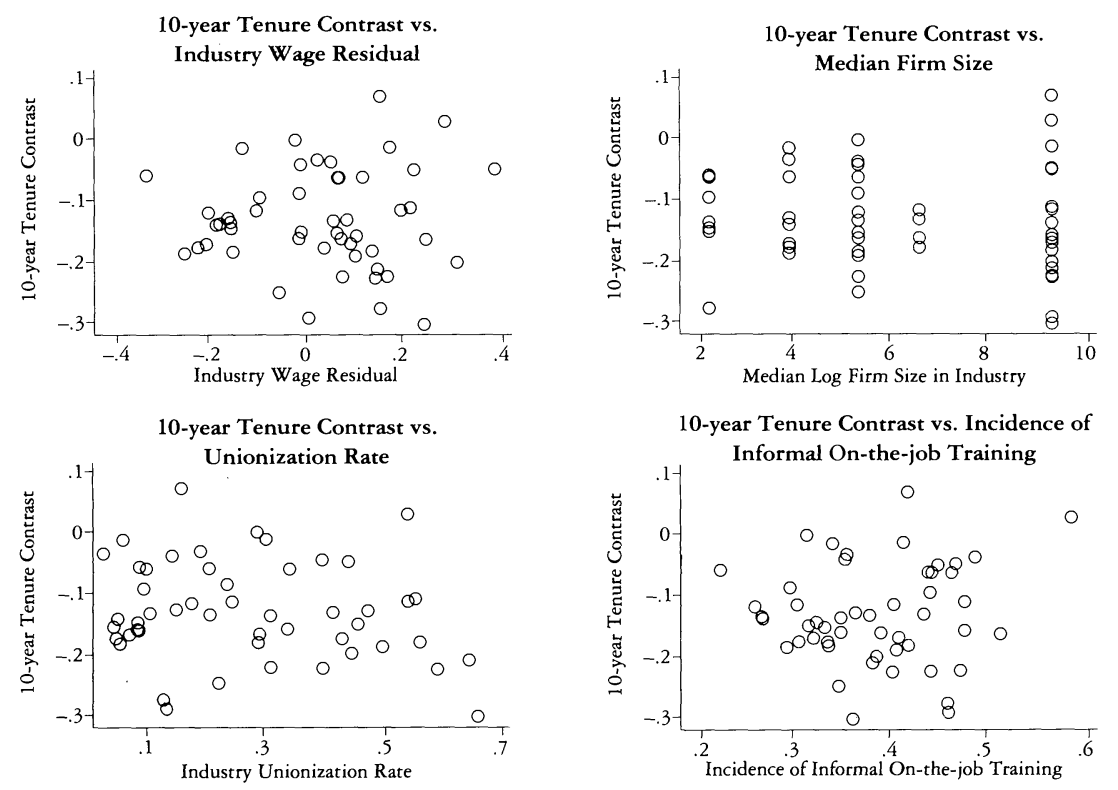

FIG. 4

size and the presence of collinearity mean that we do not have enough information to sort out the relative importance of these factors.

Panel A shows that estimated wage residuals, firm size, unionization rates, and the incidence of informal training can explain some of the interindustry variation in the costs of job displacement. While this is important in and of itself, the result also carries implications for sources of intraindustry variation in the costs of displacement. With minor exceptions, existing data sets do not contain joint information on displacement and these characteristics of a worker's job environment. ${ }^{33}$ Given this fact, the only way to assess the role of these factors in displacement adjustment is to conduct some sort of aggregated analysis. The above results are therefore the first to provide any hard evidence that firm size and on-the-job training affect the size of displacement-induced wage reductions and are among the first to document a role for unionization and "wage residuals."

Panels B and C simply confirm the inference suggested by figures 4 and 5. These industry features do not explain interindustry variation in the tenure and experience profiles of postdisplacement wage reductions. The lack of a relationship is perhaps not surprising because there are weak theoretical reasons to believe that industry wage residuals, firm size, or

${ }^{33}$ The Panel Study for Income Dynamics does contain worker-specific information on unionization. 

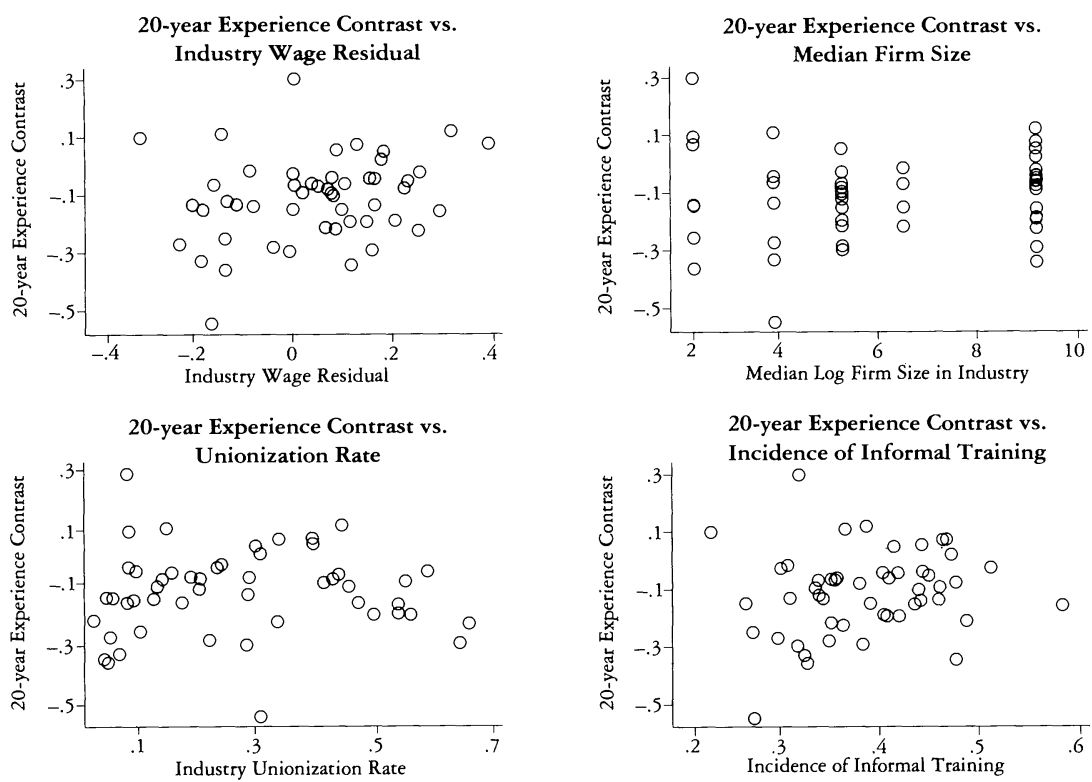

FIG. 5

unionization rates affect the tenure or the experience profile of displacement-induced wage reductions. However, human capital theory does suggest that workers' receiving on-the-job training will generate more firmspecific human capital. As a result, it is a bit surprising that the incidence of training does so little to explain interindustry variation in the tenure and experience contrasts.

\section{Conclusions}

This article has analyzed interindustry variation in the costs of job displacement. Our main finding is that most industries are clustered around a few centralized characteristics. These characteristics are that a representative displaced worker is reemployed at a roughly $13 \%$ weekly wage cut, that a worker with 10 years of predisplacement tenure loses about $12 \%$ more than a similar worker with no tenure, and that a worker with 20 years of experience loses about $9 \%$ more than a similar worker with no experience. However, we also found that there were some important outliers on each dimension.

These results carry implications for the optimal design of displacedworker assistance programs and for our views of interindustry variation in the nature of the employment relationship. For example, the results suggest that job displacement is much more costly for workers in the manufacturing and mining industries than it is for those in the service 


\section{Table 6}

\section{Sources of Interindustry Variation}

Independent Variable

(1)

(2)

(3)

(4)

(5)

A. Dependent variable $=\mathrm{EB}$ intercept:

Intercept

Industry wage residual

Median industry firm size

Industry unionization rate

Incidence of informal onthe-job training

Adjusted $R^{2}$

B. Dependent variable $=\mathrm{EB}$ 10-year tenure contrast:

Intercept

Industry wage residual

Median industry firm size

Industry unionization rate

Incidence of informal onthe-job training

Adjusted $R^{2}$

C. Dependent variable $=\mathrm{EB}$

$\begin{array}{ccccc}-.136 & -.084 & -.101 & .009 & -.036 \\ (.011) & (.031) & (.021) & (.063) & (.109) \\ -.225 & \ldots & \ldots & \ldots & -.084 \\ (.071) & \ldots & & & (.152) \\ \ldots & -.010 & \ldots & \ldots & .001 \\ & (.005) & & & (.006) \\ \ldots & \ldots & -.165 & \ldots & -.107 \\ & & (.063) & & (.088) \\ \ldots & \ldots & \ldots & -.402 & -.209 \\ .155 & .090 & .109 & (.160) & (.261) \\ & & .115 & .129\end{array}$

$-.13$

$(.012)$

.011

...

.129

20-year experience contrast:

Intercept

Industry wage residual

Median industry firm size

Industry unionization rate

.

-.117
$(.030)$
$\ldots$
-.002
$(.004)$
$\ldots$

\section{$-.110$}

$-.169-.093$

$(.021) \quad(.063)$

(.112)

-.

(.156)

$\begin{array}{lll}\cdots & \ldots & -.003\end{array}$

$(.006)$

$\begin{array}{lll}-.082 & \cdots & -.127\end{array}$

$\ldots \quad \ldots$

(.063)

(.091)

$\begin{array}{lllll}\ldots & \ldots & \ldots & \ldots & .095\end{array}$

$-.020$

$-.014$

.014

(.161)

(.269)

$-.013$

$-.016$

Incidence of informal onthe-job training

Adjusted $R^{2}$

$\begin{array}{ccccc}-.122 & -.134 & -.114 & -.235 & .096 \\ (.021) & (.054) & (.037) & (.111) & (.194) \\ .222 & \ldots & \ldots & \ldots & .557 \\ (.128) & \ldots & & & (.269) \\ \ldots & .004 & \ldots & \ldots & -.006 \\ \ldots & (.008) & .006 & & (.011) \\ \ldots & \ldots & .006 & \ldots & -.199 \\ & & (.113) & & (.157) \\ \ldots & \ldots & \ldots & .318 & -.360 \\ .040 & -.017 & -.020 & . .283) & . .464) \\ & & .005 & .031\end{array}$

NOTE.-This table reports the results of regressions of the estimated displacement-related characteristics of each industry on more fundamental industry level features. The analysis is at the two-digit level so that $n=50$ for each regression. The dependent variable in panel A is the predicted wage reduction for a standardized worker, as estimated by the empirical Bayes method described in the text. The dependent variable in panel B is the model's prediction of the difference in wage reductions for two workers that are similar but for their different number of years on the predisplacement job. The dependent variable in panel C is the model's prediction of the difference in wage reductions for two workers that are similar but for their different number of years of general labor market experience prior to displacement. 
industries and that, as a result, workers in those industries might have a more valid claim to public adjustment assistance. Similarly, the results suggest that a worker's earnings power is much more firm-specific in some industries than in others.

After documenting interindustry variation in the costs of job displacement, we moved on to ask why this variation exists. We found that interindustry variation in the average cost of displacement can be partially explained by interindustry variation in wage residuals, firm size, unionization rates, and the incidence of informal training. These findings suggest that these factors may also explain much of the intraindustry variation in the costs of displacement. However, we were largely unsuccessful in explaining variation in the tenure and experience profiles of displacement costs.

While not our main focus, this article also makes a methodological point. There are many instances in which economists are interested in estimating models with a family of parameters that are likely to be similar but unlikely to be exactly the same. Examples from labor economics include the estimation of industry wage residuals, the estimation of state-level unionization rates, and the estimation of occupation-specific training rates. In such cases where the data are insufficient to allow precise estimation of each specific parameter, then the econometrician must ask whether there is additional information that can be brought to bear on the problem. We argue that empirical Bayes procedures, adopted from the statistical literature, are an attractive technique for incorporating valid prior information. Although empirical Bayes techniques have not been widely used in econometric studies to date, we hope that the present study will motivate their consideration in future analyses.

\section{Appendix}

\section{Variable Definitions}

Variable

TENURE

TENURE2

EXPERIENCE

EXPERIENCE2

EDUCATION

PLANTCLOSED

STATETREND

STATESHOCK

\section{Definition}

Years with predisplacement job

TENURE squared

Years of potential labor market experience at date of displacement at date of displacement (age - education - 6)

EXPERIENCE squared

Years of completed education

$=1$ if displaced from plant that closed completely.

$=0$ if displaced from plant that continued to operate at a reduced employment level.

Mean log state employment change over 3 years prior to displacement. Data are drawn from County Business Patterns (see text for discussion).

Deviation of state log employment from predicted 
INDTREND

INDSHOCK

WAGECHANGE trend log employment. Data are drawn from County Business Patterns (see text for discussion).

Mean log state $X$ two-digit industry employment change over 3 years prior to displacement. Data are drawn from County Business Patterns (see text for discussion).

Deviation of state $x$ two-digit industry $\log$ employment from predicted trend log employment. Data are drawn from County Business Patterns (see text for discussion).

Adjusted difference in log weekly wages between pre- and postdisplacement jobs. In particular, we first compute (log postdisplacement weekly wage) - (log predisplacement weekly wage). We then regress this quantity on the above variables, an intercept, and 14 survey-year/displacement-year dummies (three surveys $\times 5$ years per survey - one left-out group). The left-out group was the surveyed-in-1988/displaced-in-1987 group. We then subtracted the estimated survey-year/ displacement-year effects from each person's individual wage change and called the resulting number WAGECHANGE. This procedure serves to equalize the mean change in log wages across survey-year/displacement-year cells, save for variation that can be explained by the above variables. See text for full discussion.

Note.-All data are drawn from the 1984, 1986, and 1988 Displaced Worker Surveys, except where noted.

\section{References}

Addison, John T., and Portugal, Pedro. "The Effects of Advance Notification of Plant Closings on Unemployment." Industrial and Labor Relations Review 41 (October 1987): 3-15.

Akerlof, George, and Yellen, Janet. "Unemployment through the Filter of Memory." Quarterly Journal of Economics 100 (August 1985): 737-53.

Becker, Gary. Human Capital. New York: National Bureau of Economic Research, 1962.

Blattberg, Robert, and George, Edward. "Shrinkage Estimation of Price and Promotional Elasticities: Seemingly Unrelated Equations." Journal of the American Statistical Society 86 (June 1991): 304-15.

Brown, Charles, and Medoff, James. "The Employer Size-Wage Effect." Journal of Political Economy 97 (October 1989): 1027-59.

Carrington, William J. "Wage Losses for Displaced Workers: Is It Really the Firm That Matters?" Journal of Human Resources 28 (Summer 1993): 435-62. 
Farber, Henry S. "The Incidence and Costs of Job Loss: 1982-91.” Brookings Papers on Economic Activity, no. 1 (1993), pp. 73-132.

Fay, Robert E., and Herriot, Roger A. "Estimates of Income for Small Places: An Application of James-Stein Procedures to Census Data." Journal of the American Statistical Society 74 (June 1979): 269-77.

Howland, Marie, and Peterson, George. "Labor Market Conditions and the Reemployment of Displaced Workers." Industrial and Labor Relation: Review 42 (October 1988): 109-22.

Jacobson, Louis; LaLonde, Robert; and Sullivan, Daniel G. "Earnings Losses of Displaced Workers." American Economic Review 83 (September 1993): 685-709.

Juhn, Chinhui; Murphy, Kevin M.; and Pierce, Brooks. "Wage Inequality and the Rise in Returns to Skill." Journal of Political Economy 101 (Jun€ 1993): 410-42.

Kletzer, Lori G. "Returns to Seniority after Permanent Job Loss." Americar Economic Review 79 (June 1989): 536-43.

- .Earnings after Job Displacement: Job Tenure, Occupation, Industry." In Job Displacement: Consequences and Implications for Policy, edited by John T. Addison. Detroit: Wayne State University Press, 1991.

Kokkelenberg, Edward C., and Sockell, Donna R. "Union Membership in the United States: 1973-1981." Industrial and Labor Relations Reviere 38 (July 1985): 497-543.

Krueger, Alan B., and Summers, Lawrence H. "Efficiency Wages and the Interindustry Wage Structure." Econometrica 56 (March 1988): 259-93.

Mills, Daniel Quinn. Labor-Management Relations, 4th ed. New York: McGraw-Hill, 1989.

Morris, Carl N. "Parametric Empirical Bayes Inference: Theory and Applications." Journal of the American Statistical Association 78 (January 1983): 47-54.

Podgursky, Michael, and Swaim, Paul. "Job Displacement and Earnings Loss: Evidence from the Displaced Worker Survey." Industrial and Labor Relations Review 40 (October 1987): 17-29.

Ruhm, Christopher. "The Time Profile of Displacement-induced Changes in Unemployment and Earnings." In Job Displacement: Consequences and Implications for Policy, edited by John T. Addison. Detroit: Wayn State University Press, 1991.

Topel, Robert. "Specific Capital and Unemployment: Measuring the Costs and Consequences of Job Loss." Carnegie-Rochester Conference Series or. Public Policy 33 (1990): 181-214.

U.S. Department of Commerce, Bureau of the Census. Statistical Abstraci of the United States. Washington, D.C.: Government Printing Office. 1987. (a)

U.S. Department of Commerce, Bureau of the Census. Enterprise Statistics. Washington, D.C.: Government Printing Office, 1987. (b)

Zellner, Arnold, and Hong, Chansik. "Forecasting International Growth Rates Using Bayesian Shrinkage and Other Procedures." Journal oj Econometrics 40 (January 1989): 183-202. 